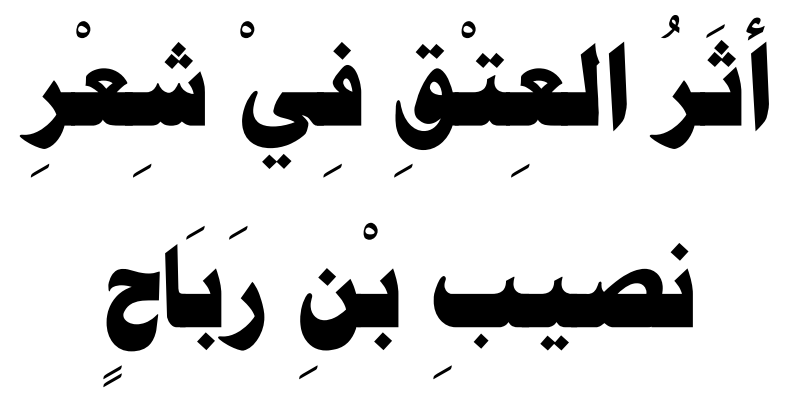

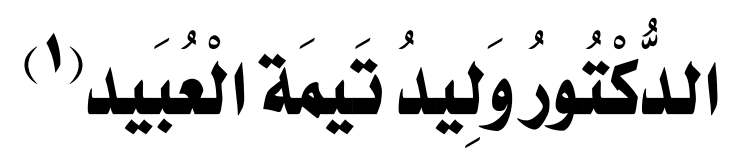

(1) أستاذ الأدب والنقد المساعد، قسم اللغة العربية، كلية التربية والآداب، جامعة تبوك. 


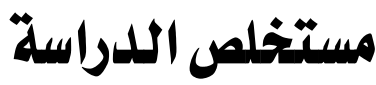

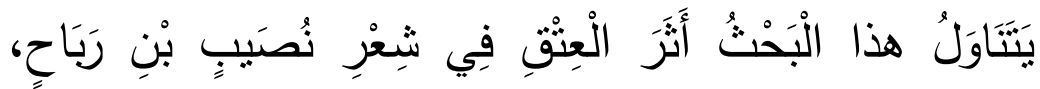

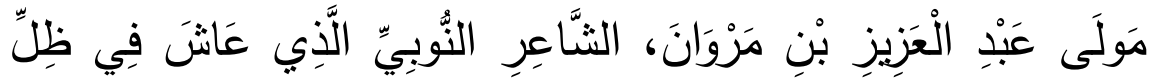

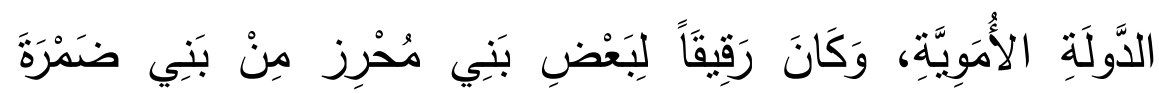

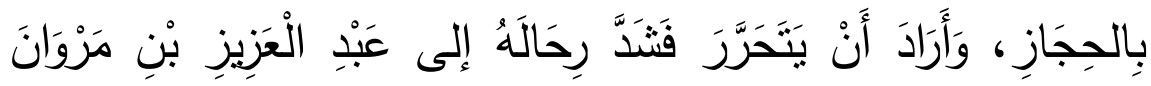

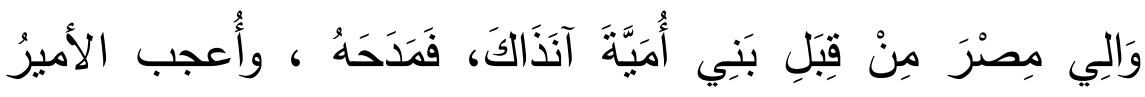

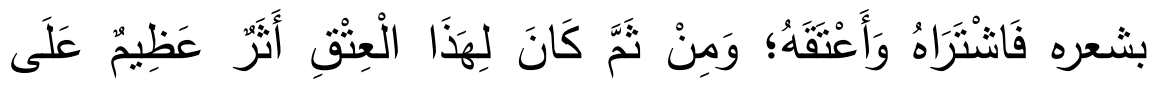

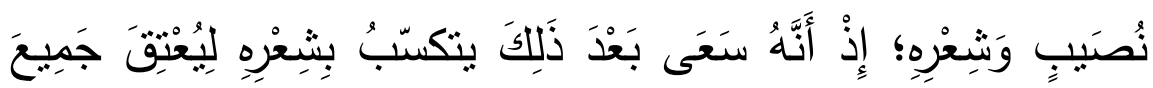

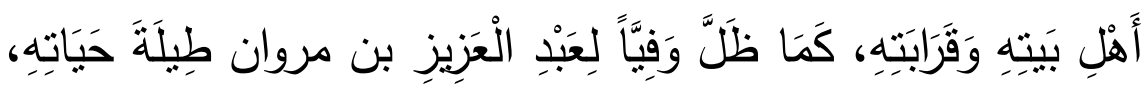

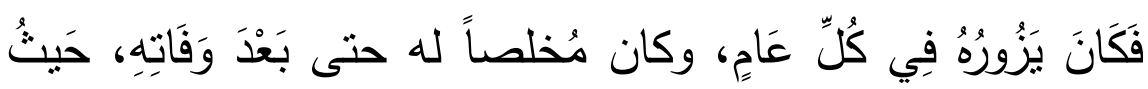

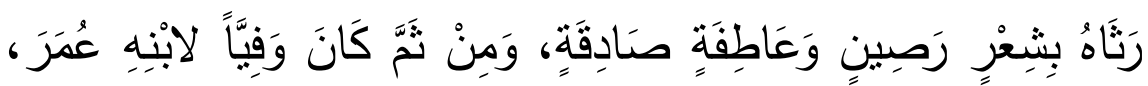

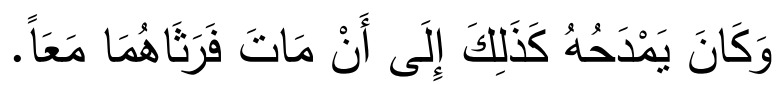




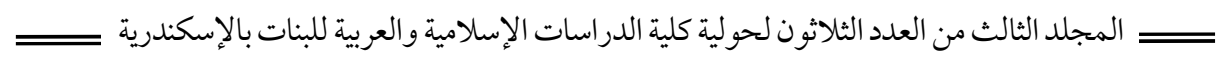

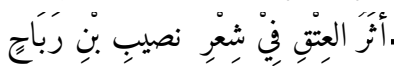




\begin{abstract}
This study deals with the influence of the manumission in the poetry of Nussaib Ibn Rabah, Servant of Abdulaziz Ibn Marwan, the Nubian Poet who lived within the confines of the Umayyad State and who was enslaved by someone from Bani Muhriz of Bani Damra in Hijaz. He wanted to free himself from bondage, so he headed to Abdulaziz Ibn Marwan, the then Umayyad ruler of Egypt. He praised him and Abdulaziz Ibn Marwan liked his poetry. He bought and freed Nussaib. This manumission has a great effect on Nussaib and his poetry. He started earning money from his poetry and used the money earned to free his family members and relatives. He also became very loyal to Abdulaziz Ibn Marwan and visited him every year. He was faithful to him even after he died he wrote sincere poetry of lamentation for his death. He also remained loyal to his son Omer and when Omer died, he wrote elegies lamenting the death of both of them.
\end{abstract}




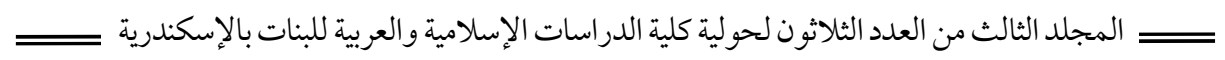

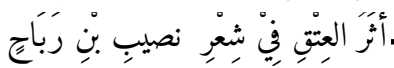




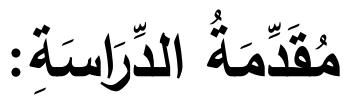

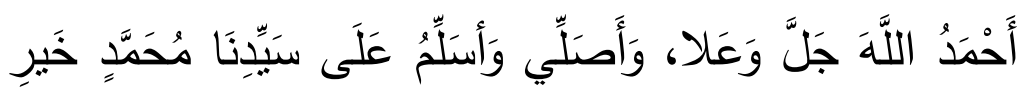

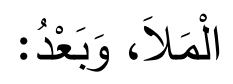

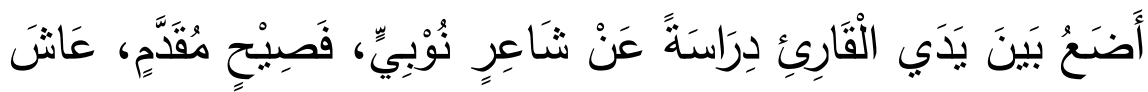

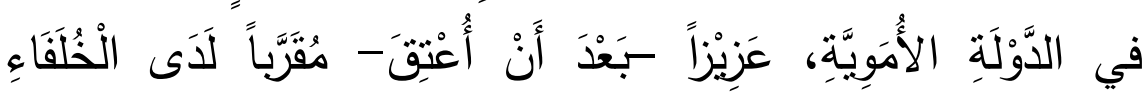

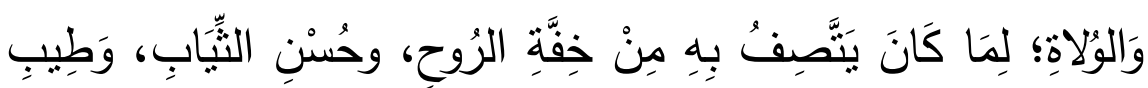

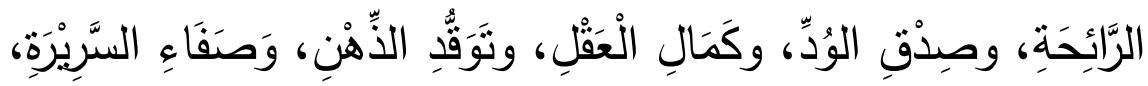

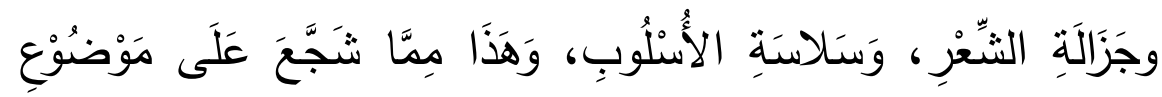

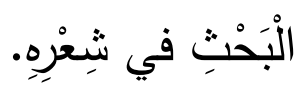

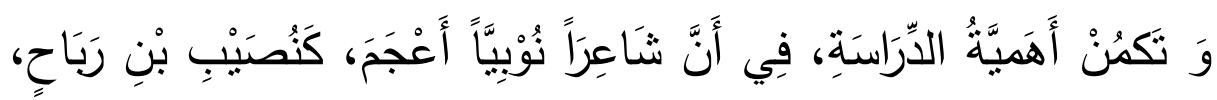

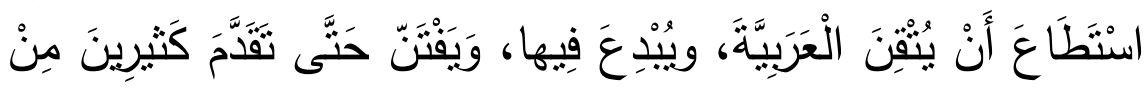

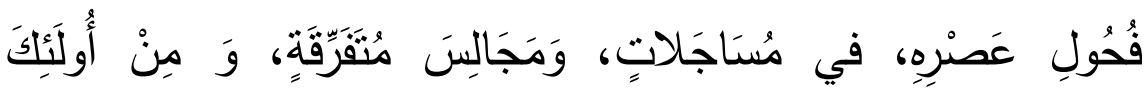

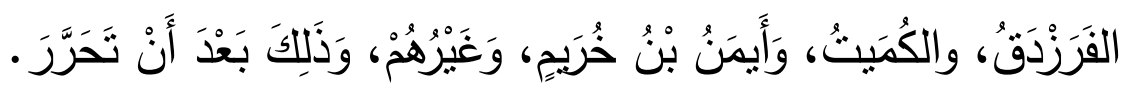

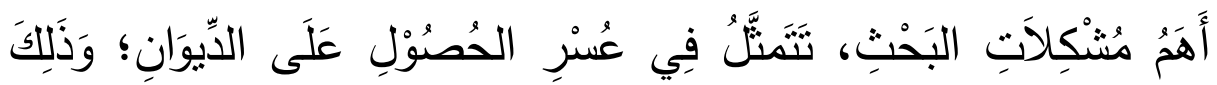

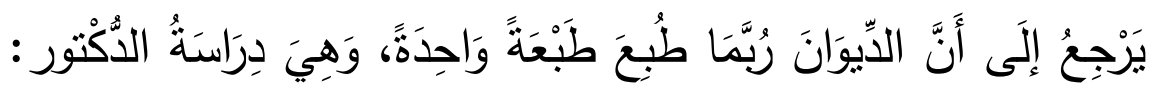

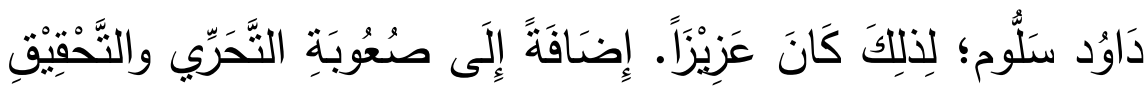

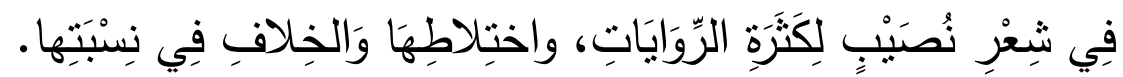

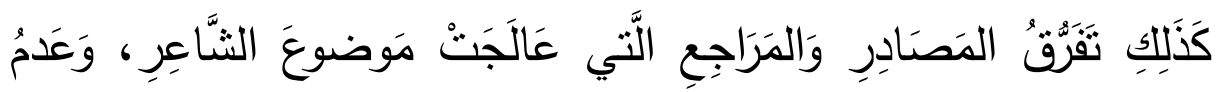

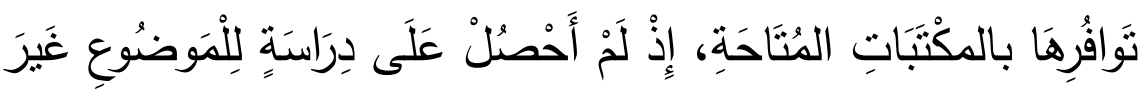

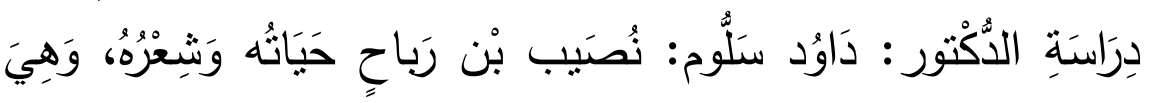




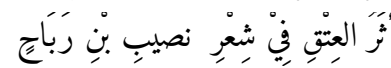

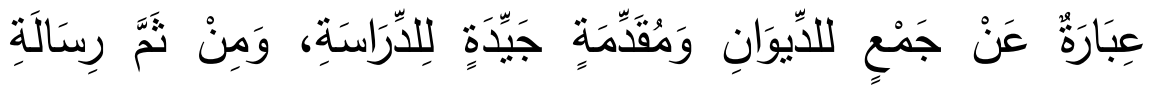

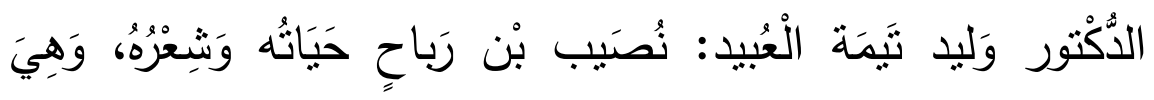

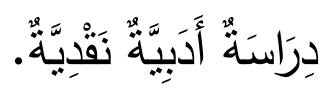

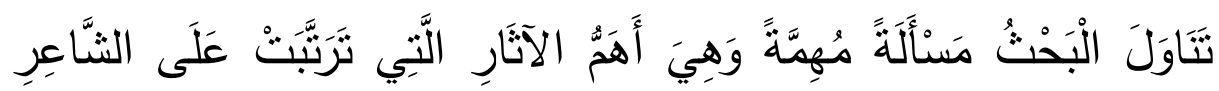

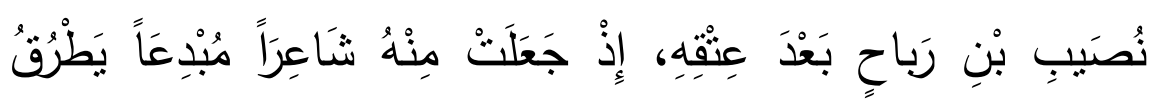

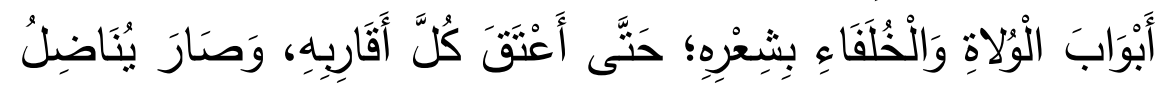

$$
\begin{aligned}
& \text { كِبَارَ شُعَرَاءِ عَصْرِهِ. }
\end{aligned}
$$

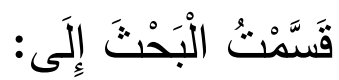

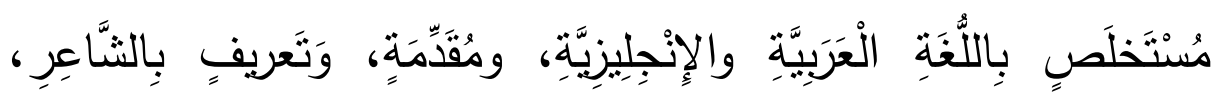

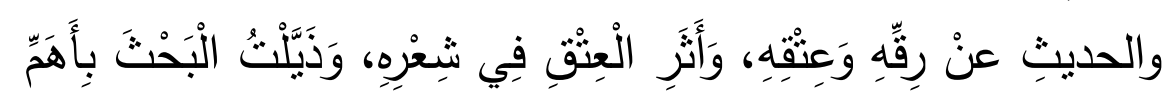

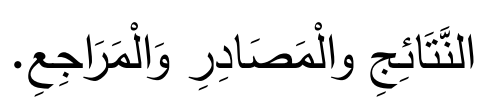




\section{التَّْْرِيفُ بِالشََّّاعِرِ}

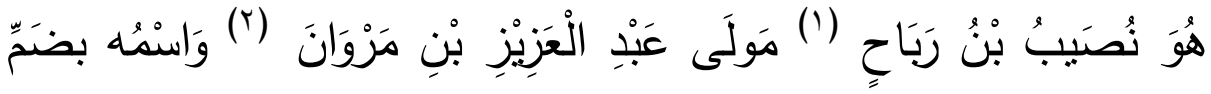

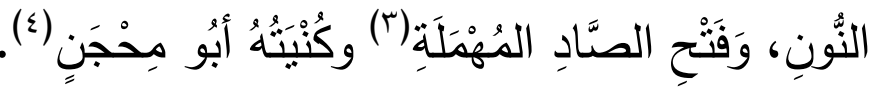

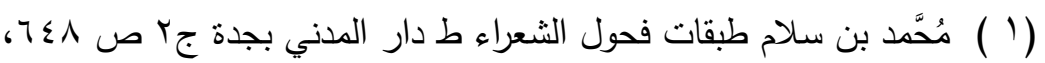

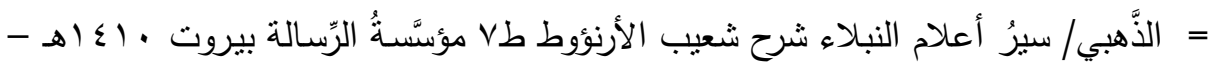
rт7/0 ؛199.

= الزركلـي - الأعـام - قـاموس تـراجم لأشـــر الرجـال والنسـاء مـن العـرب والمسـتعربين

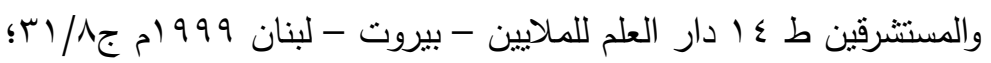

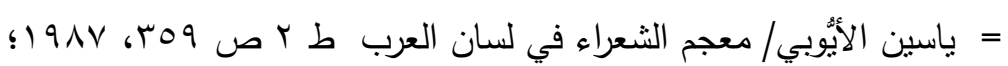

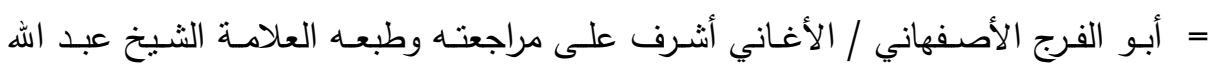

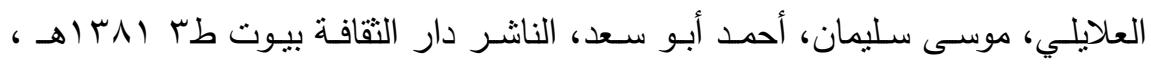

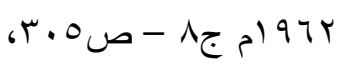

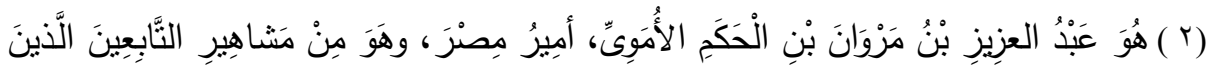

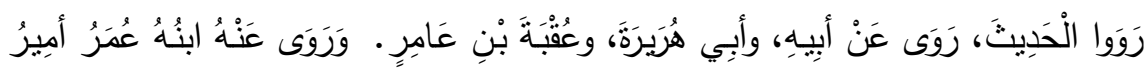

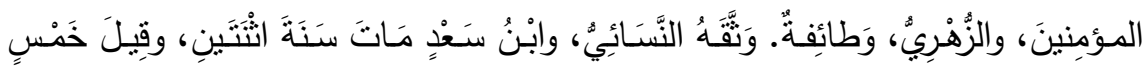

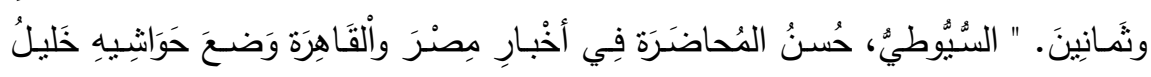

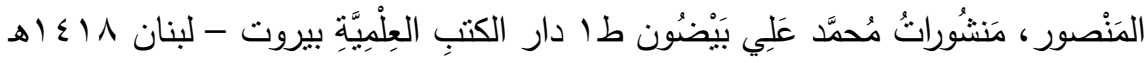

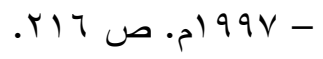

(T ) القاسم بن الحسين الخوارزمي - شرح الكُفصَّل في صَنْعَة الإعراب - الموسوم بالتخمير

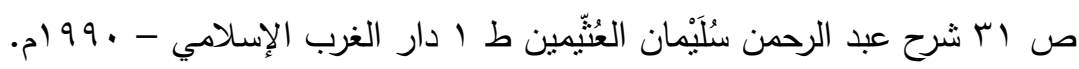

$$
\begin{aligned}
& \text { ( ) ) الذهبي (1) }
\end{aligned}
$$

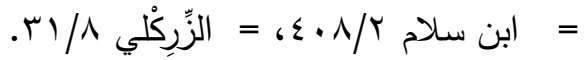




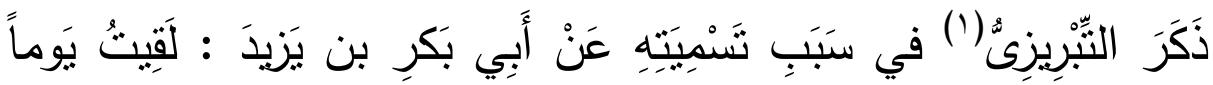

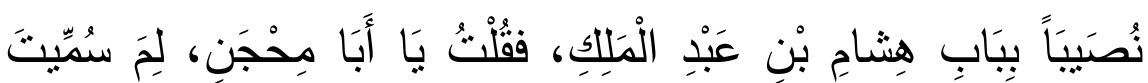

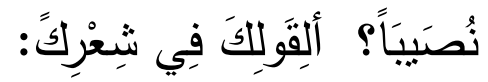

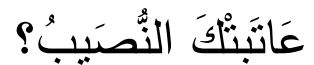

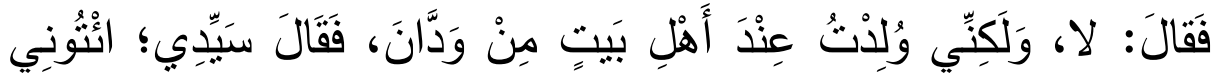

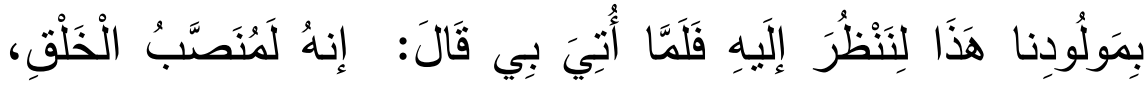

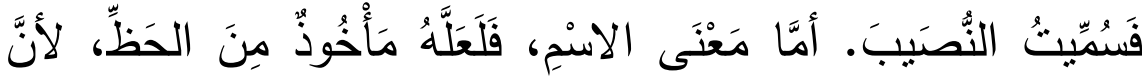

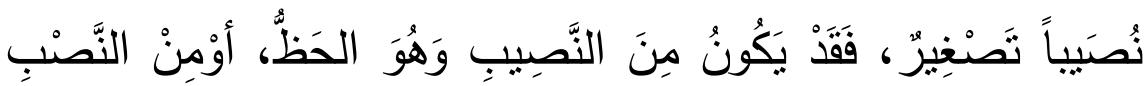

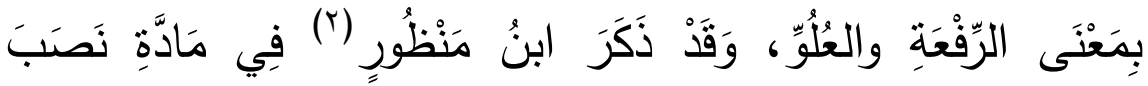

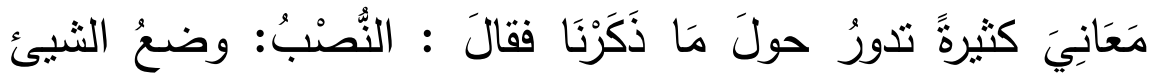

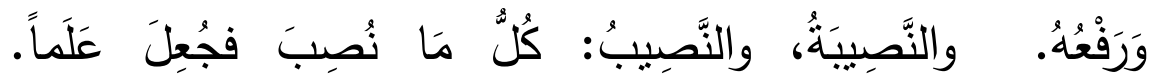

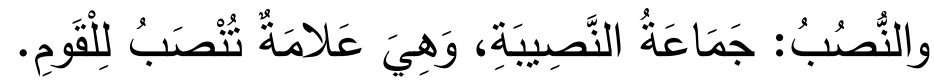

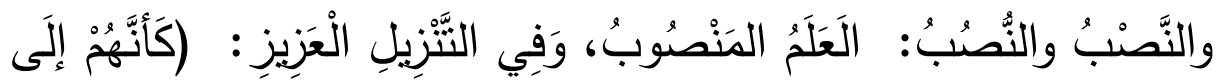

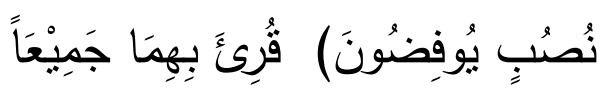

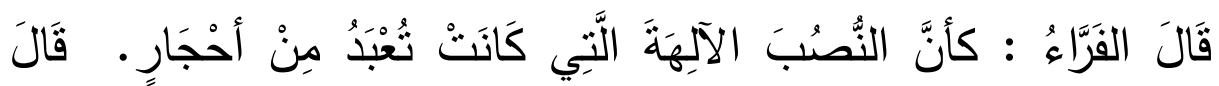

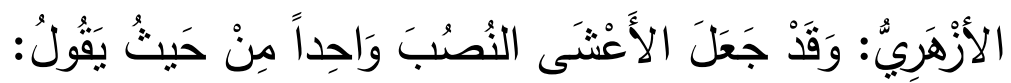

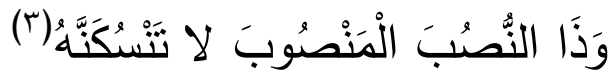

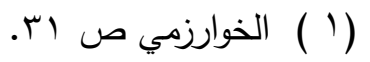

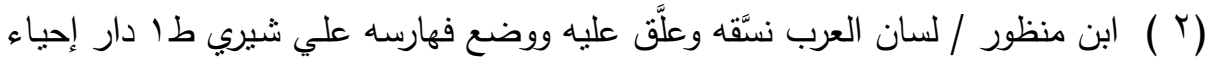

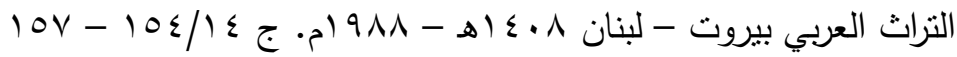

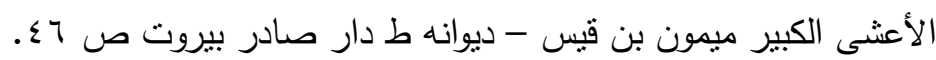




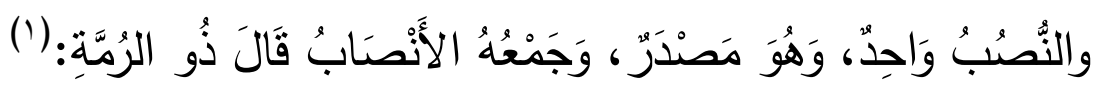

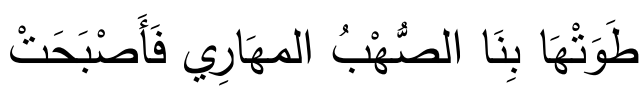

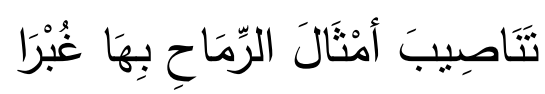

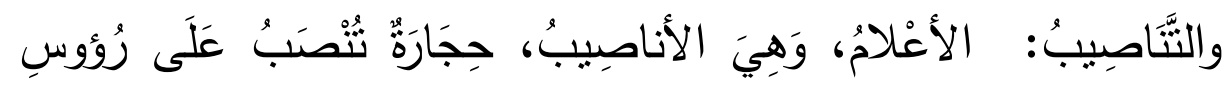

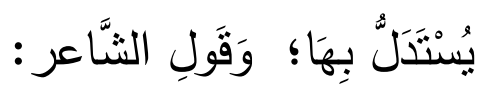

القُور (r)

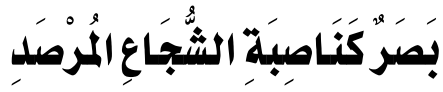

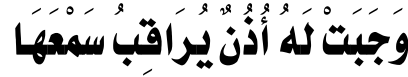

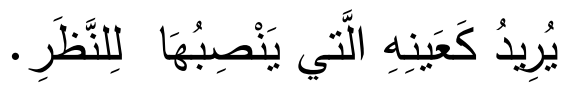

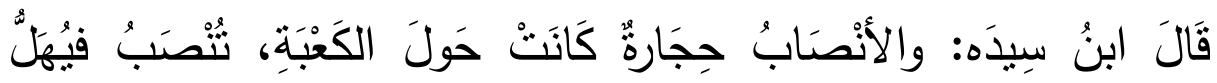

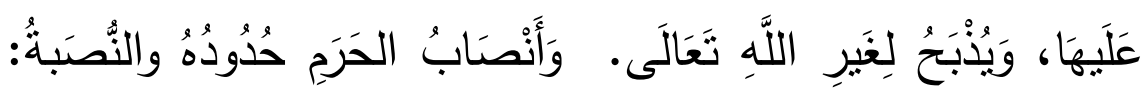

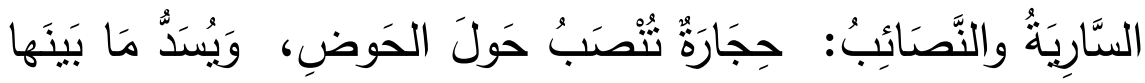

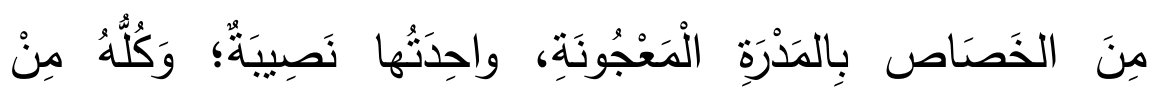

ذَلِلكَ (r).

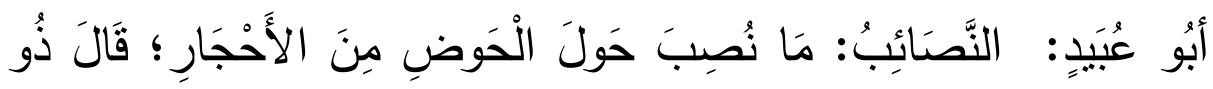

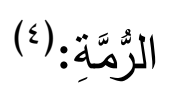

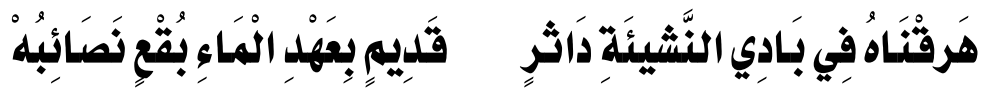

(1 ) ديوانه قدم لله وشرحه أحمد حسن بستج طا 0 إ؛ـ (اهـ - 990 ام دار الكتب العلمية ص صV.

$$
\begin{aligned}
& \text { (Y ) القُورُ جمع قارة وهي الأرض التي حجارتها سُوْدَاء. قال المنتبي: }
\end{aligned}
$$

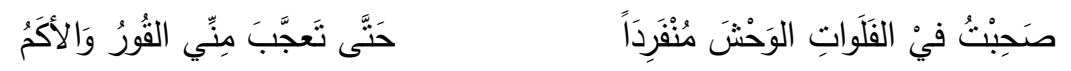

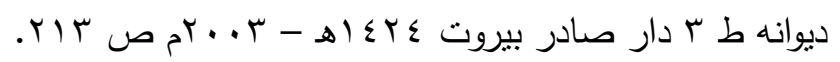

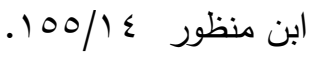

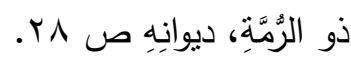




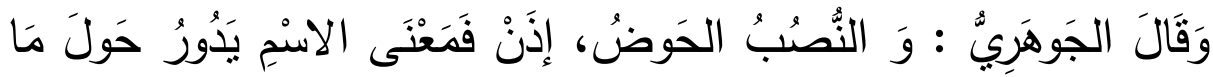

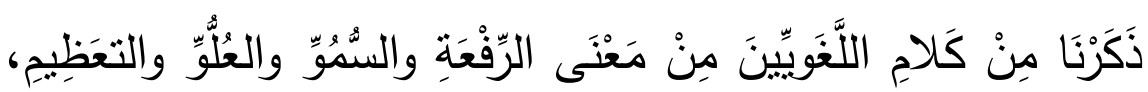

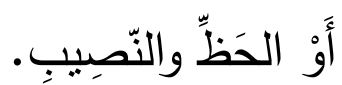

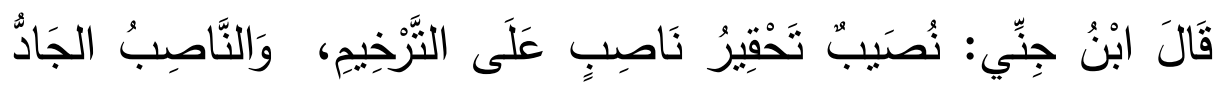

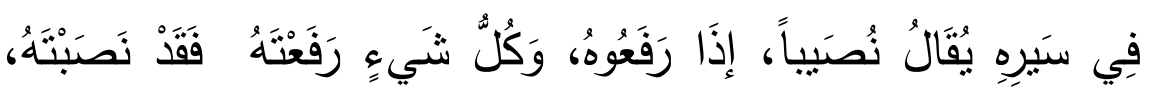

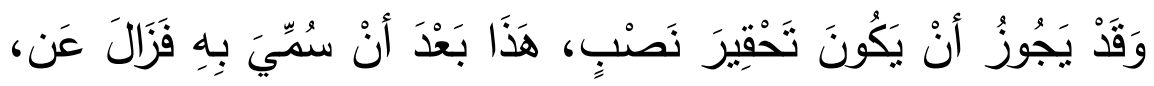
مَصندريَّتَهِ (')

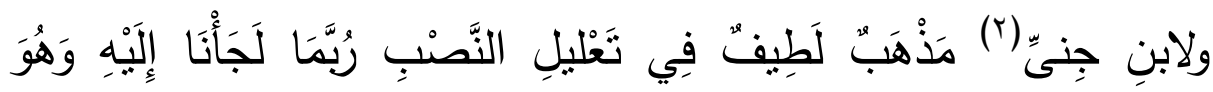

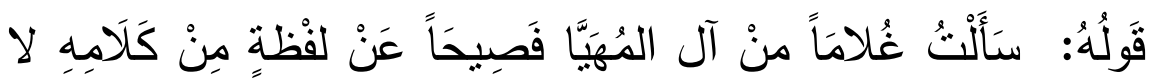

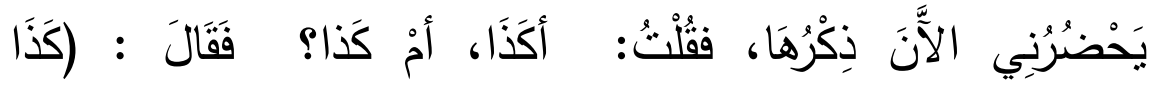

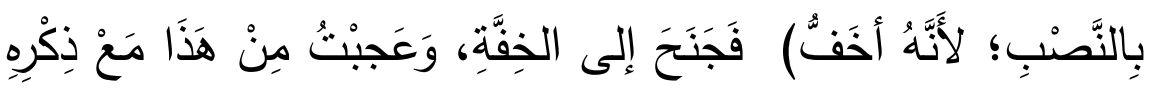

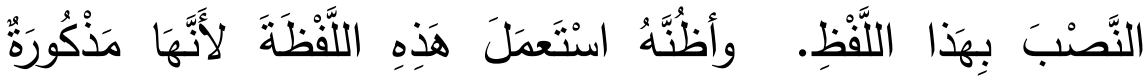

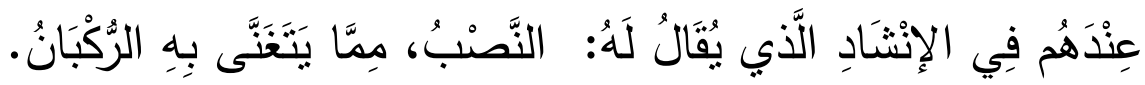

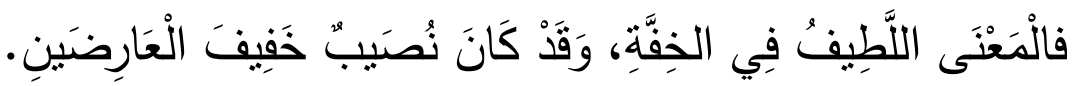

أبو الفتح عثمان بن جنـي المبهج في تقسير أسماء ديوان الحماسـة ط دار الآفاق

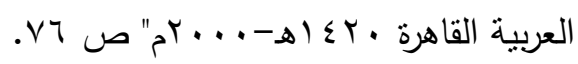

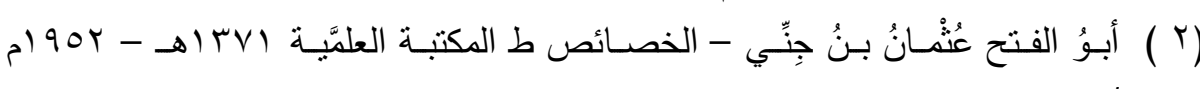
. $v N / 1$ 


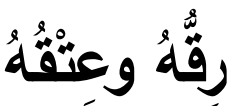

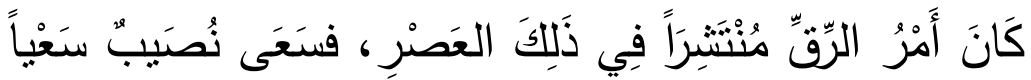

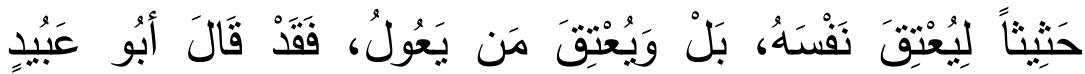

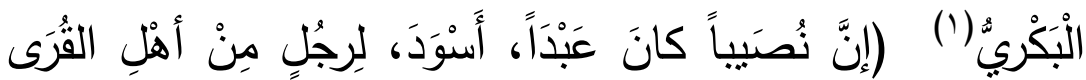

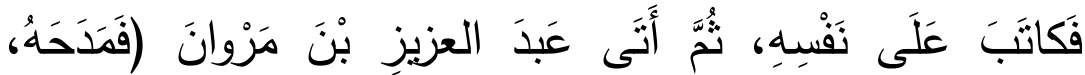

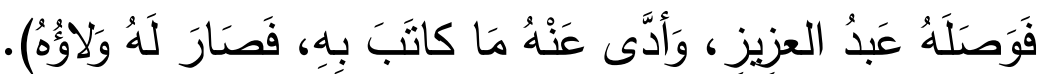

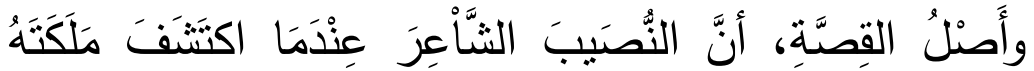

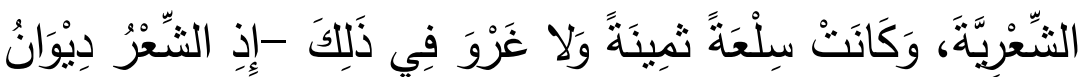

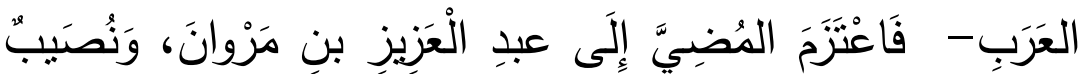

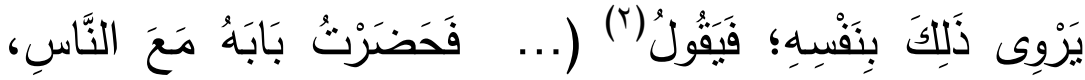

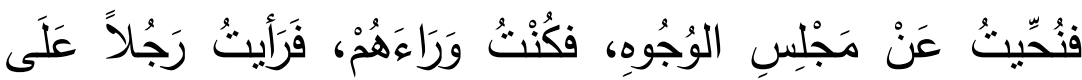

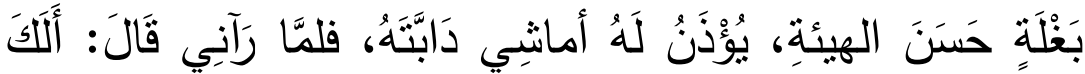

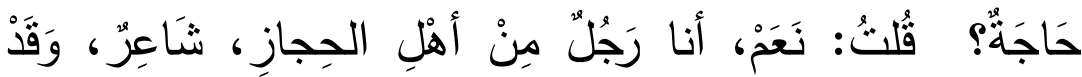

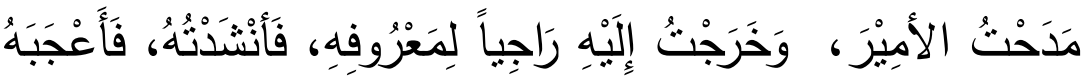

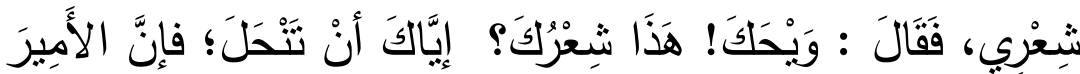

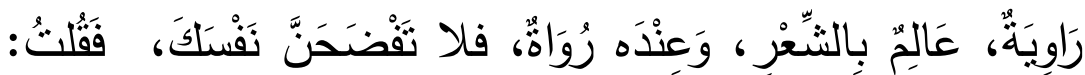

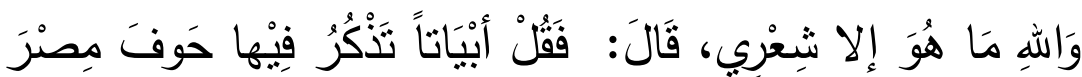

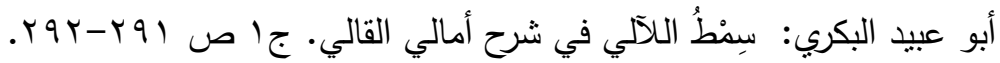

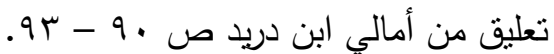




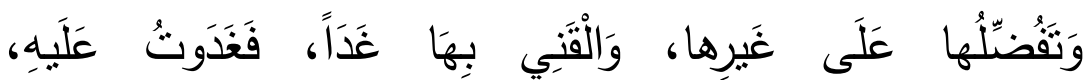

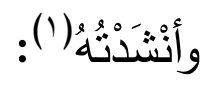

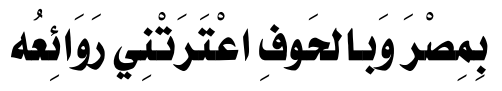

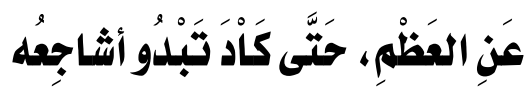

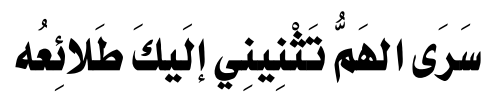

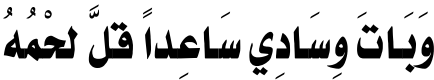

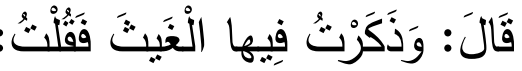

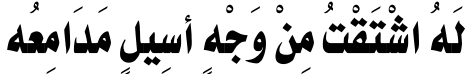

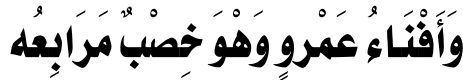

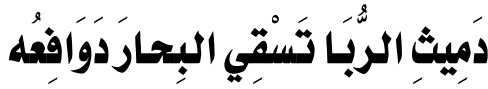

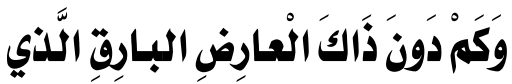

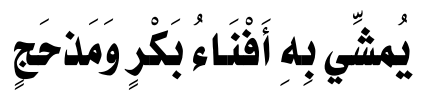

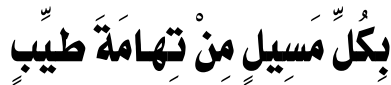

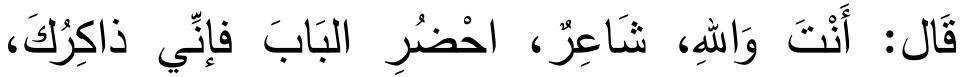

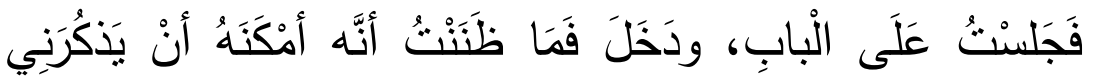

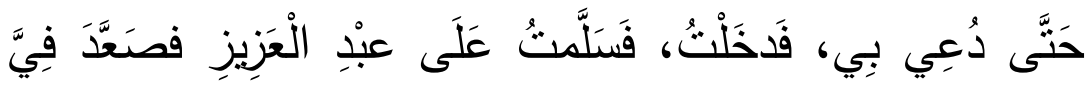

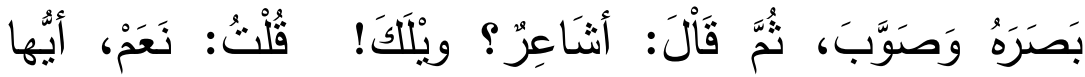

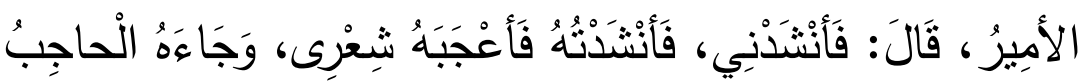

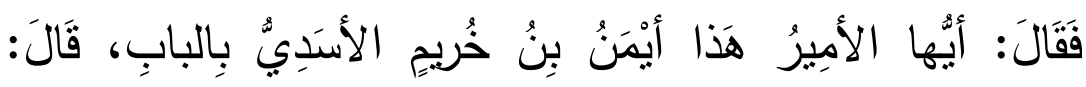

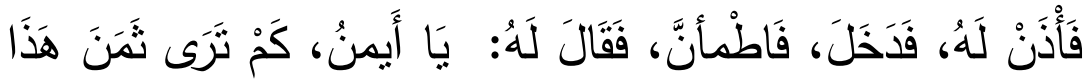

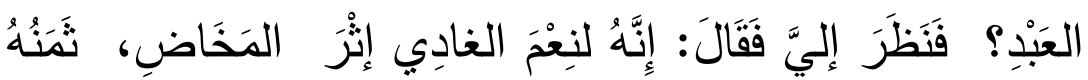

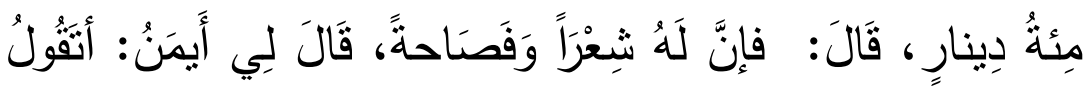

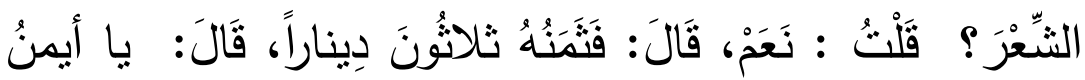

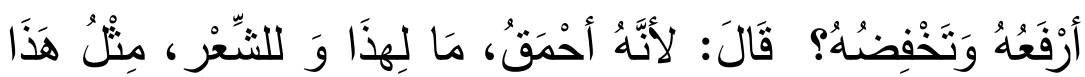




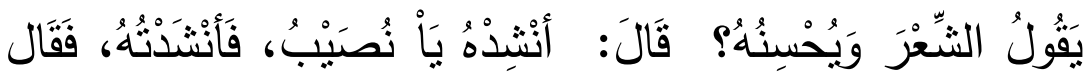

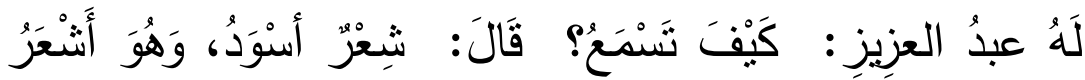

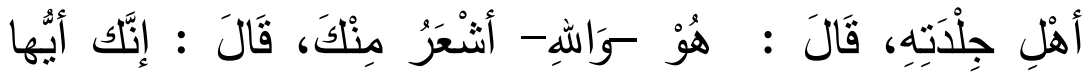

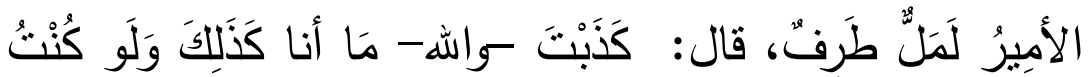

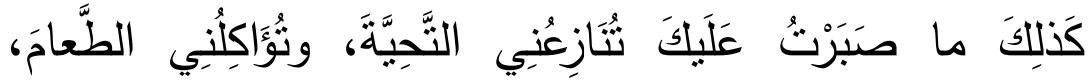

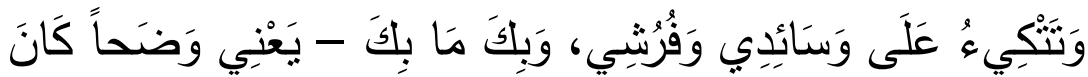

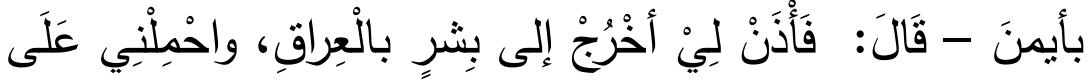

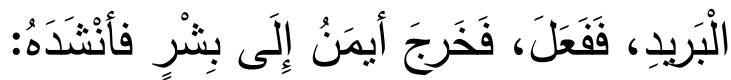

إِكَى بِشْرِ بْنِ مَرْوَانَ المبرِيدَا

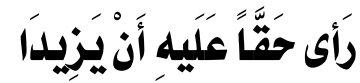

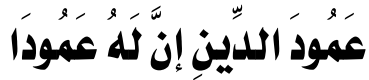

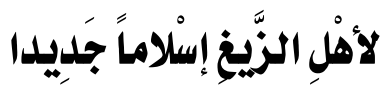

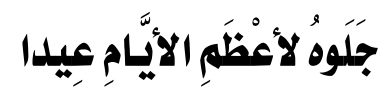

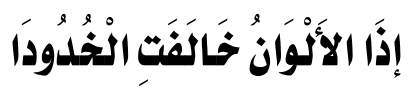

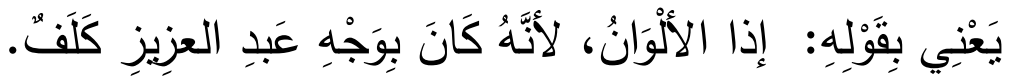

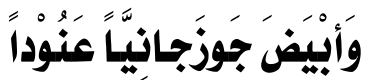

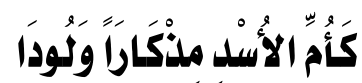

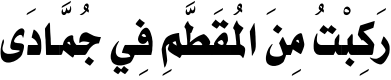

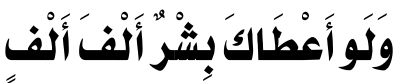
أمِيرَ المُؤْمِنِينَ أَقِمْ بِبِشْرِ

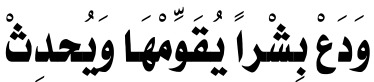

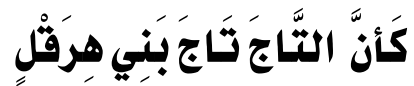
عَلَى دِيبَاجِ خَدَّيَ وَجْهِ بِشْرِ
فَأعْقِبْ مِدْحَتِى سَرَجْاَ خَلَنْجَاً

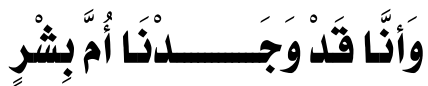

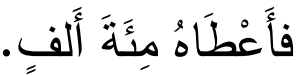




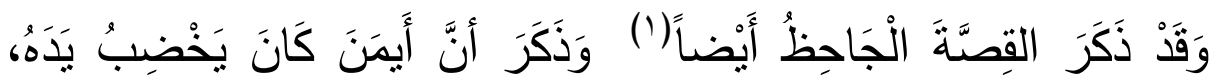

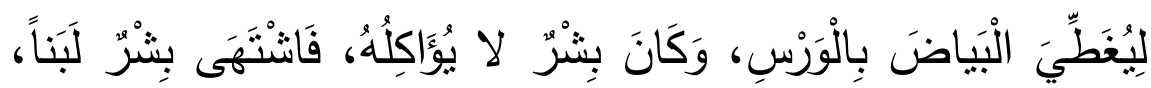

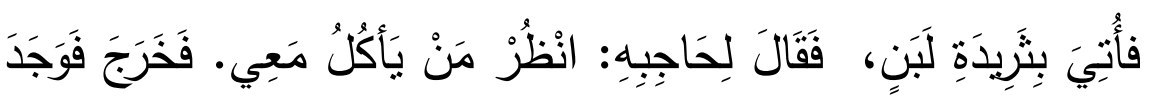

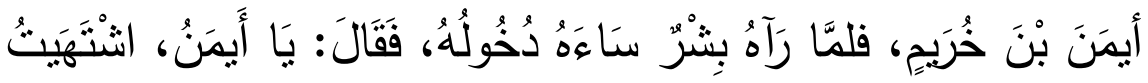

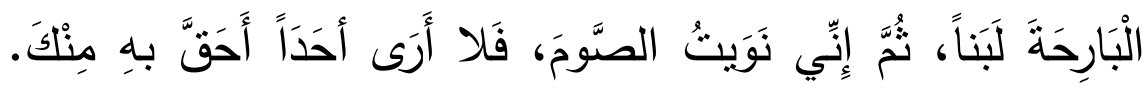

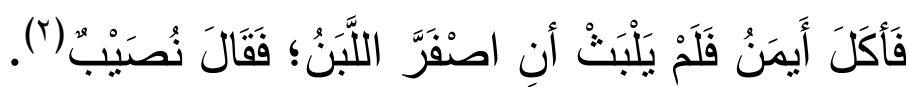

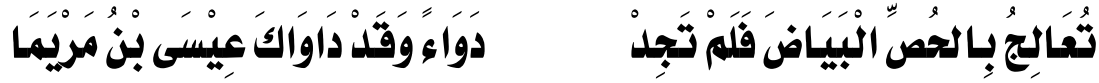

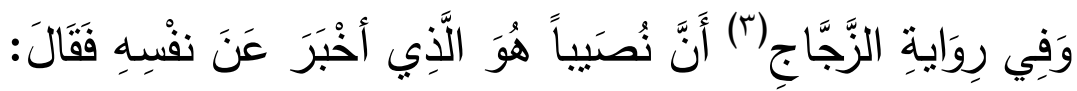

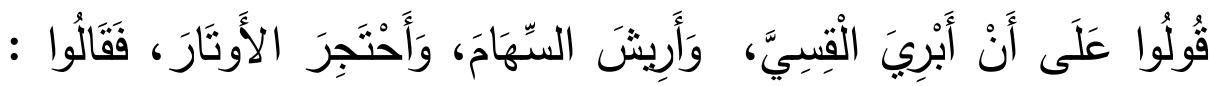

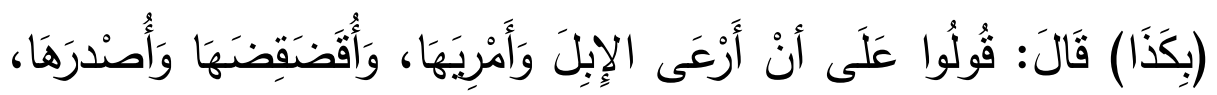

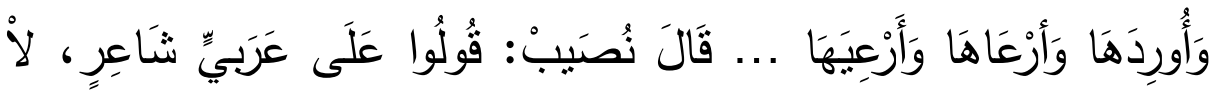

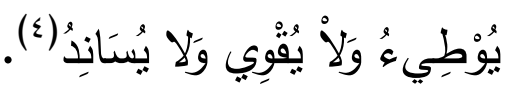

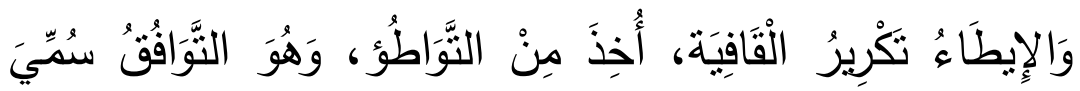

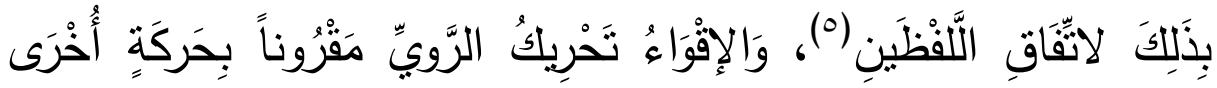

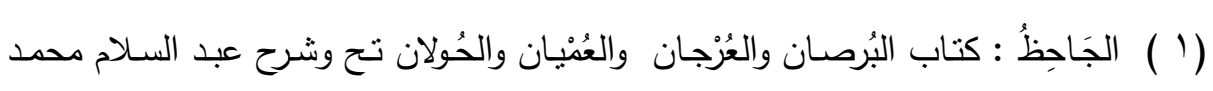

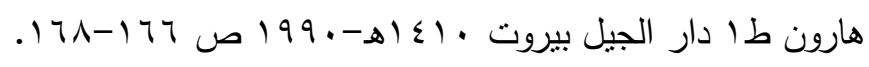
البيث غير موجود في ديوان نصيب.

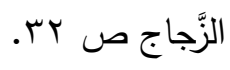

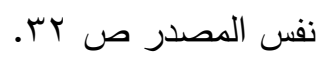

الدماميني بدر الدين أبو عبد الله محمد بن أبى بكر العيون الغامزة على خبايا الرامزة،

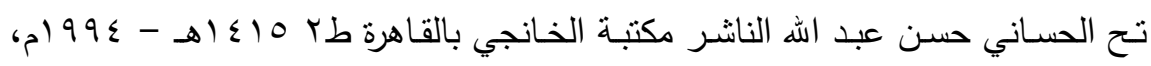




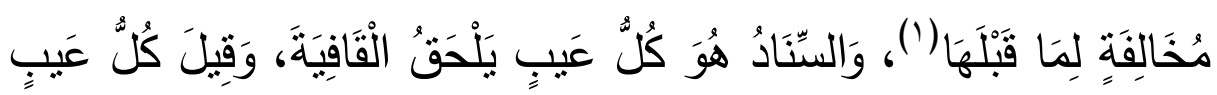

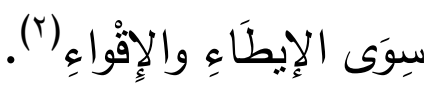

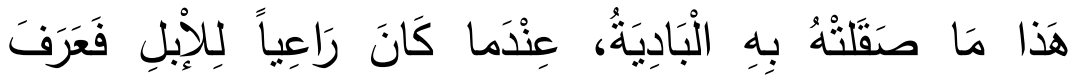

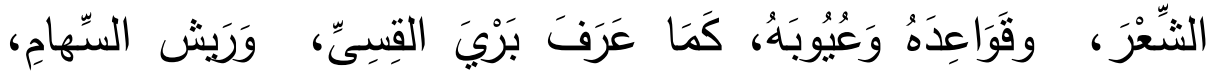

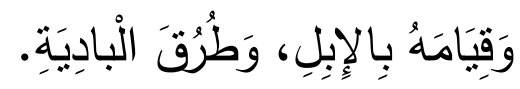

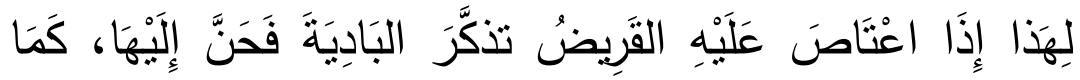

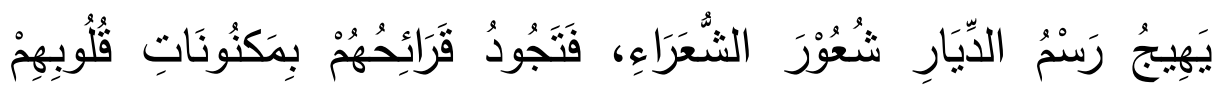

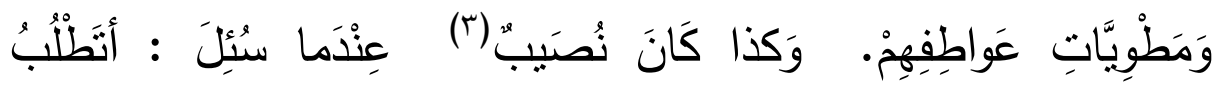

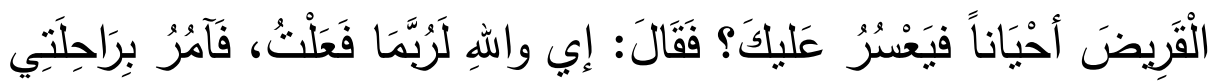

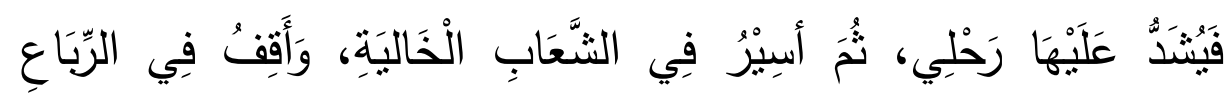

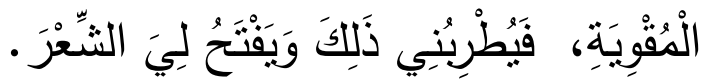

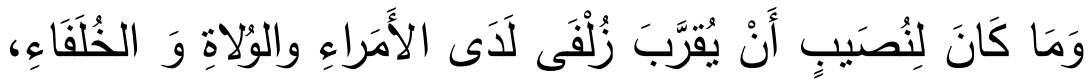

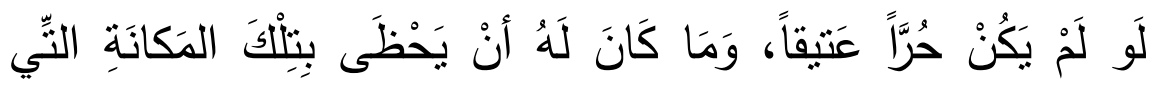

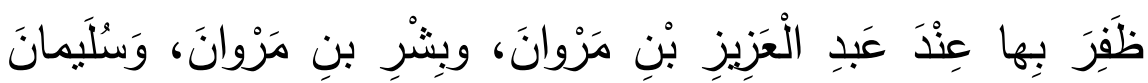

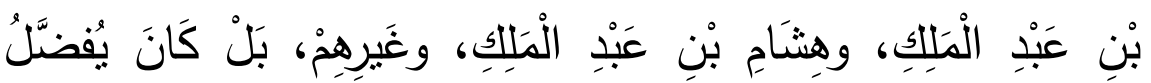

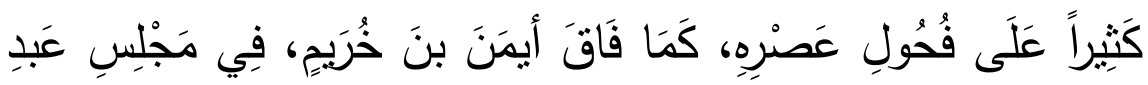

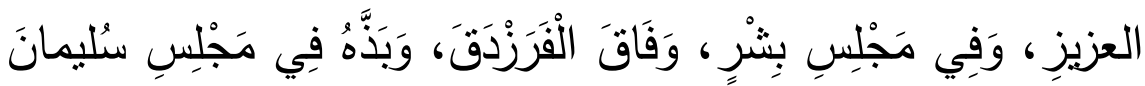

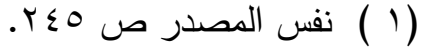

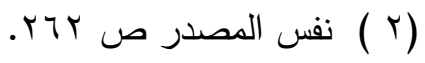

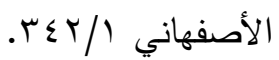




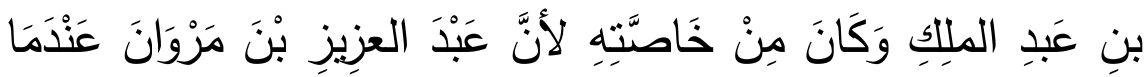

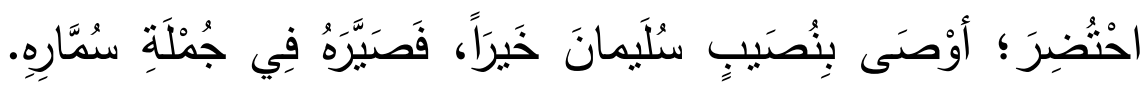

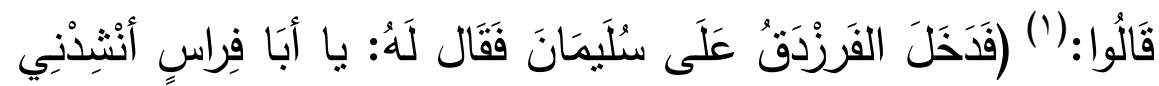

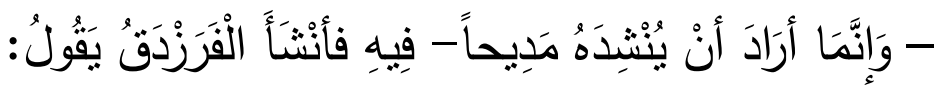

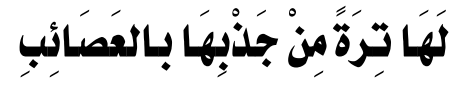

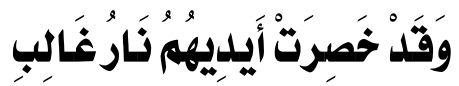

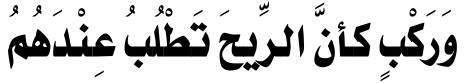

إذَا أَبْصَرْوا نَارَا يَقُولُونَ لَيَتَهَا

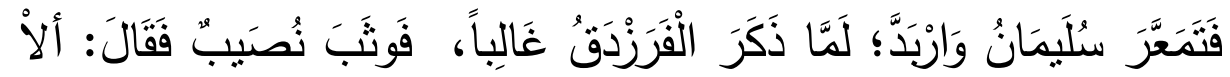

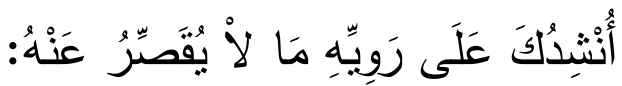

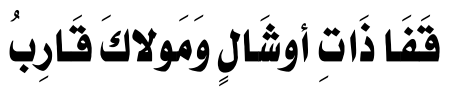

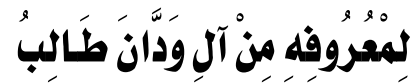

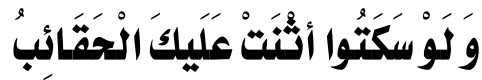

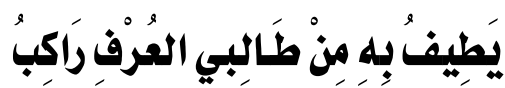

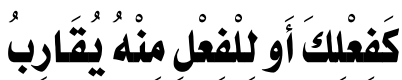

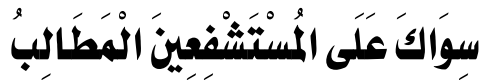

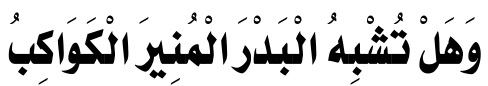

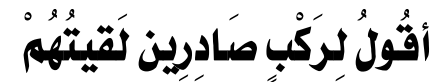

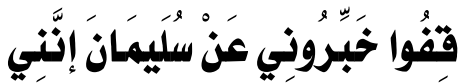

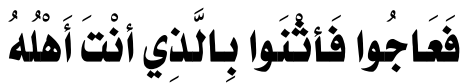

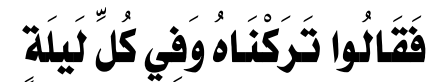

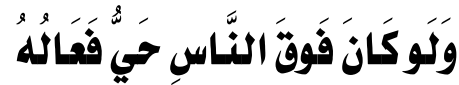

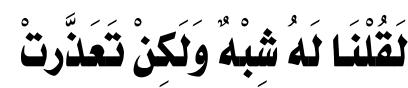

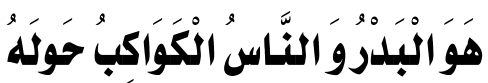

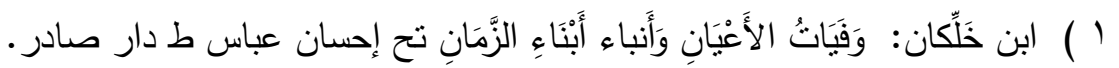

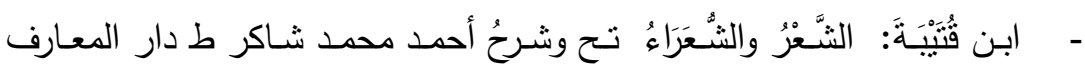

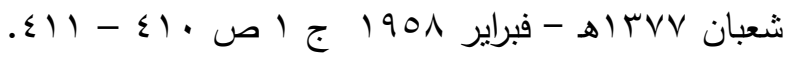

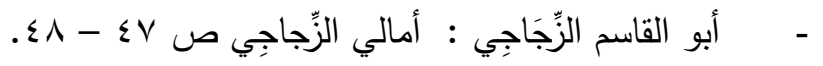

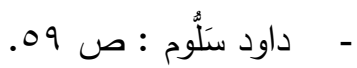




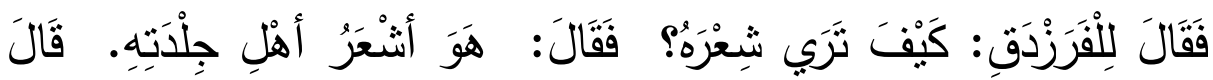

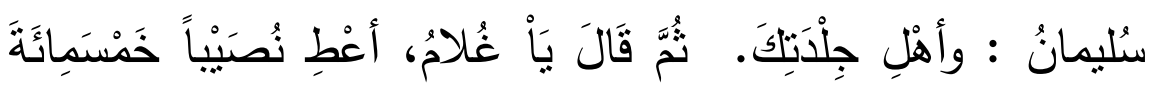

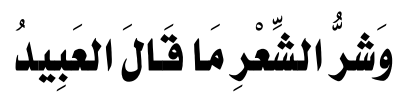

$$
\begin{aligned}
& \text { دِينَارِ، وَإِلى الْفَرَزَدَقِ نَارَ أَبِيهِ. }
\end{aligned}
$$

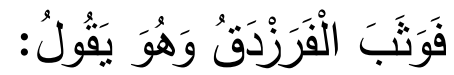

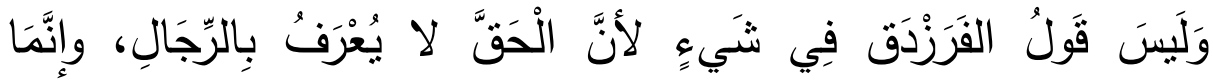

$$
\text { الرِّجَالُ يُعْرَفُوْنَ بِالْحَقِّ. }
$$

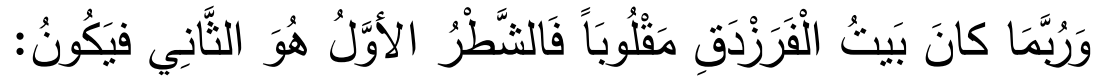

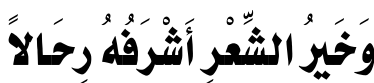

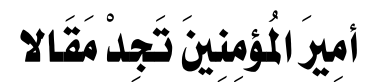

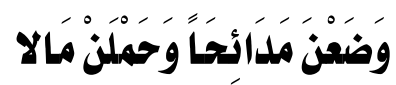

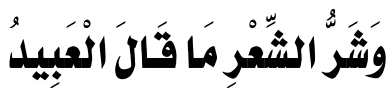

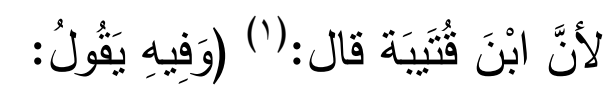

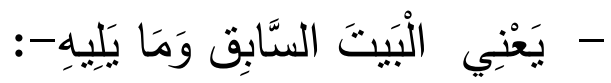

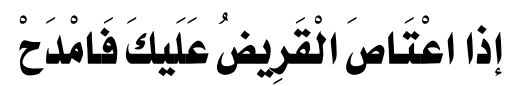

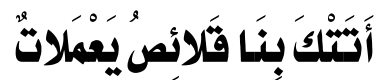

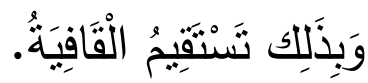

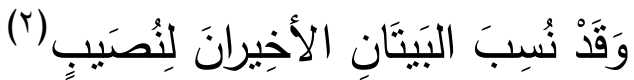

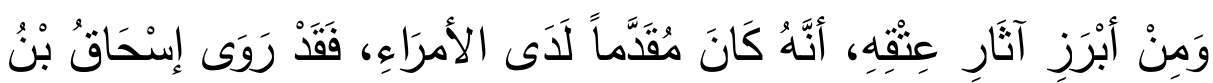

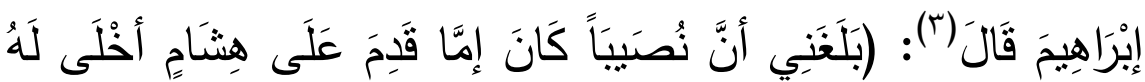

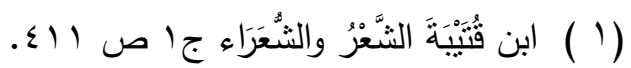

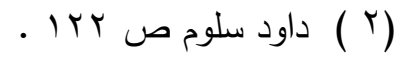

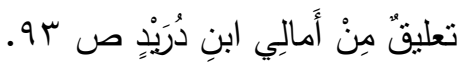

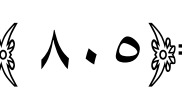




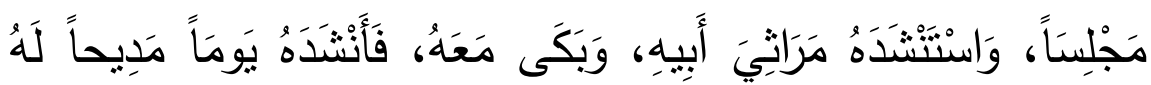

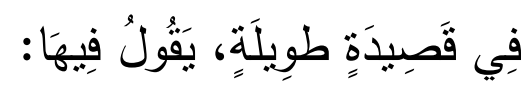

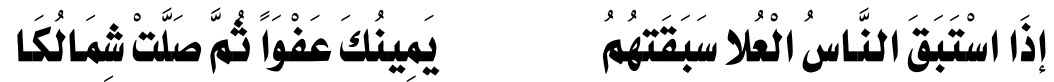

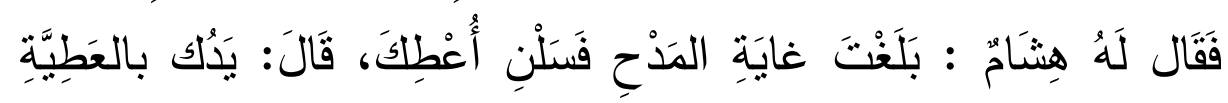

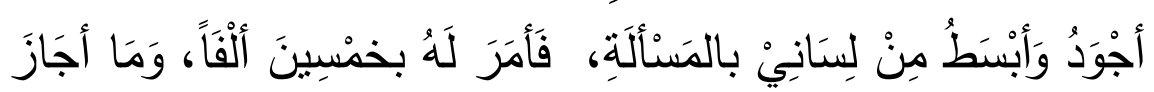

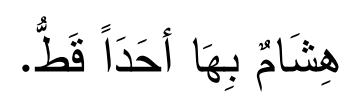

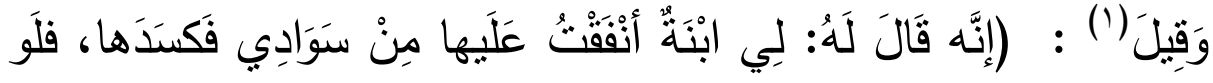

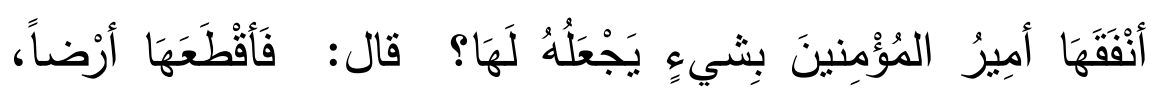

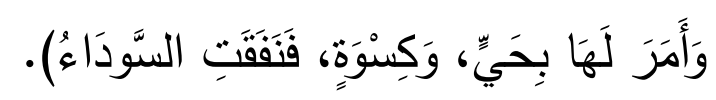

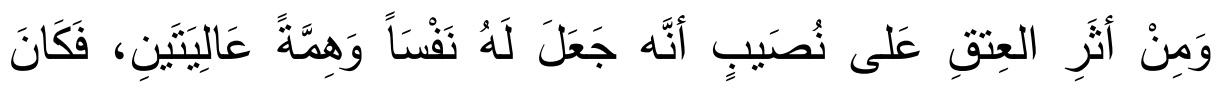

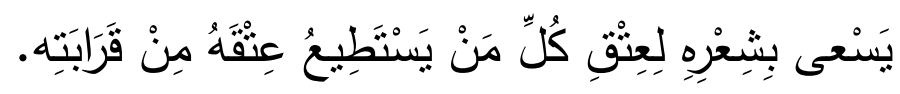

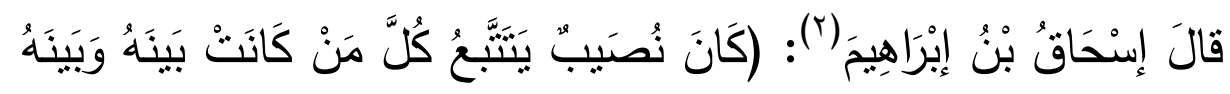

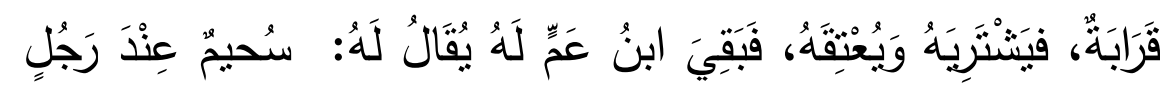

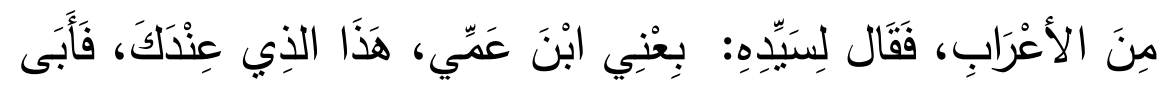

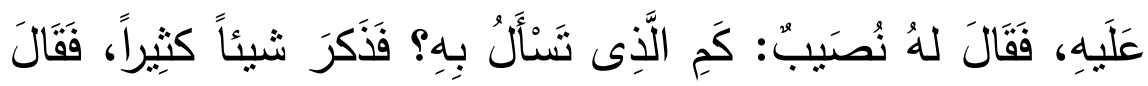

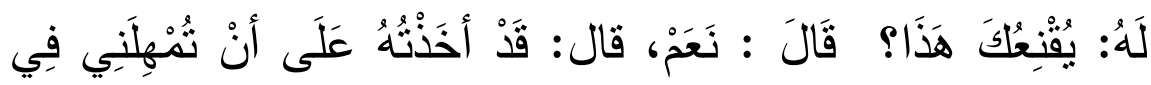

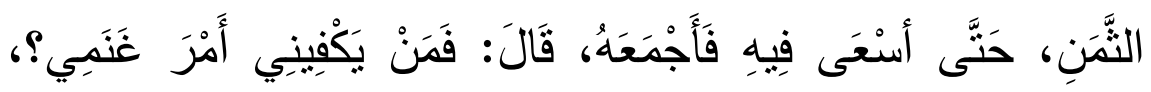




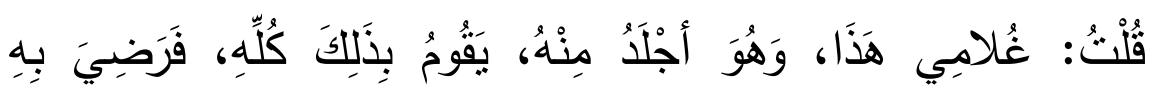

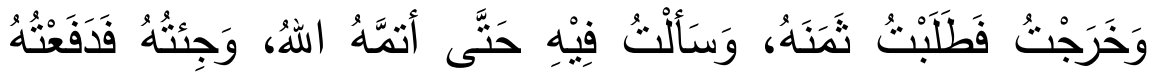

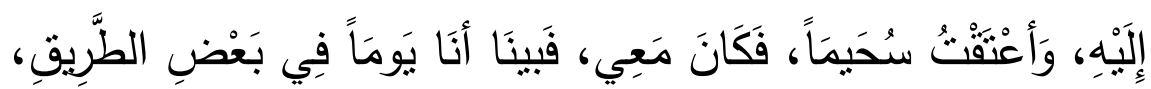

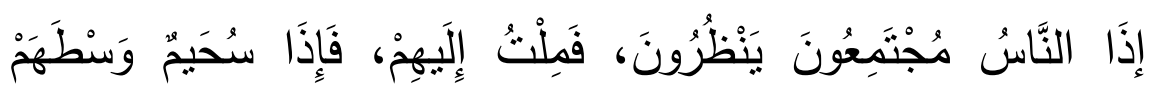

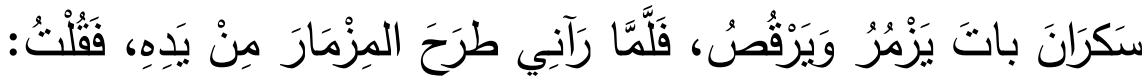

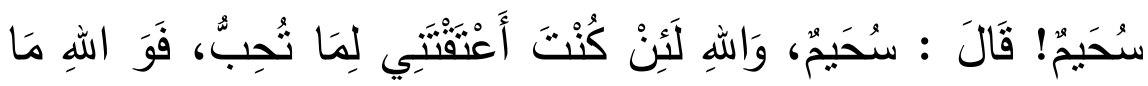

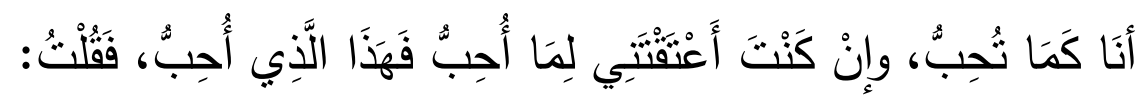

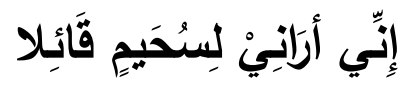

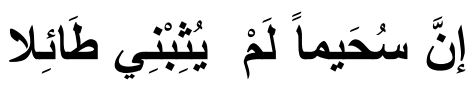

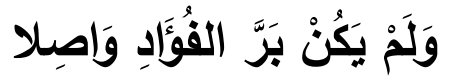

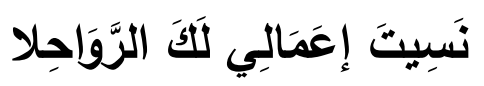

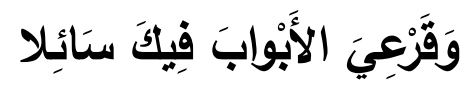

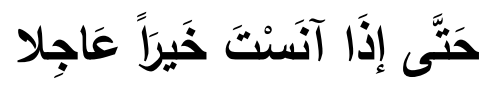

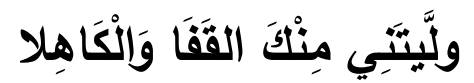

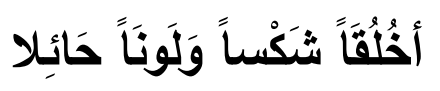

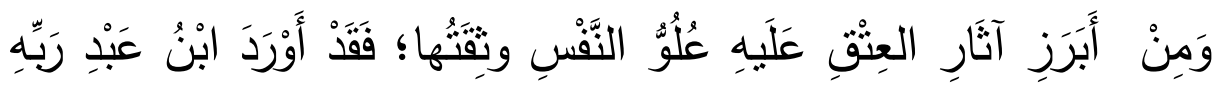

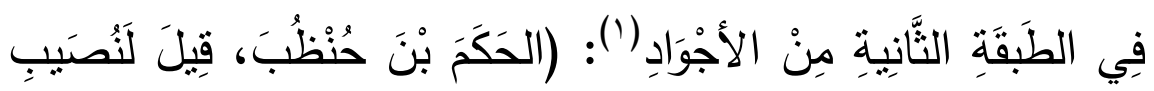

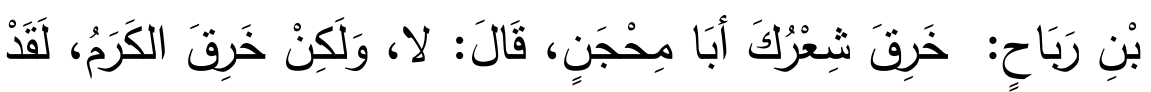




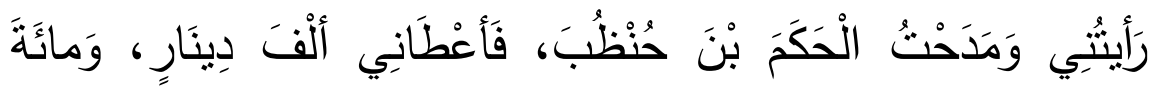

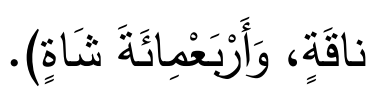

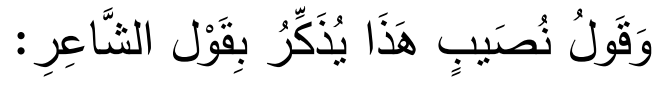

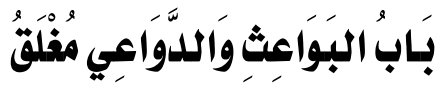

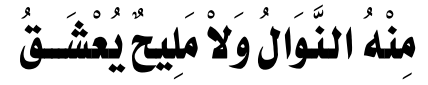

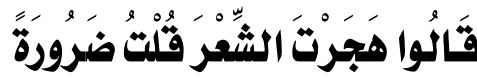

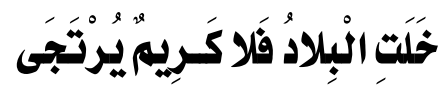

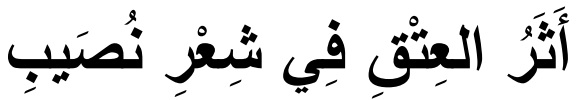

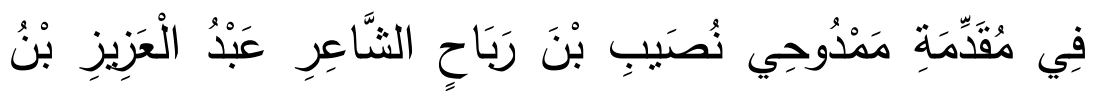

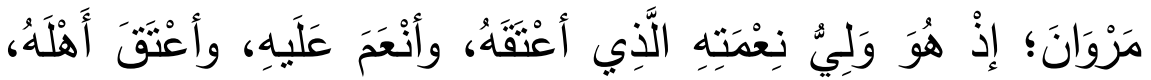

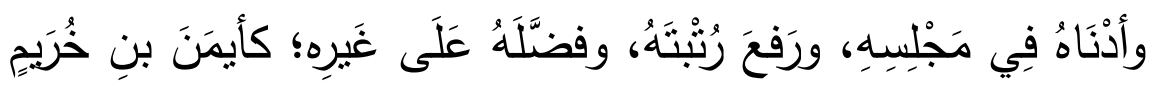

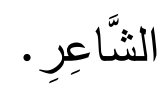

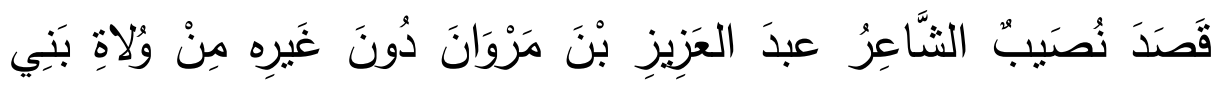

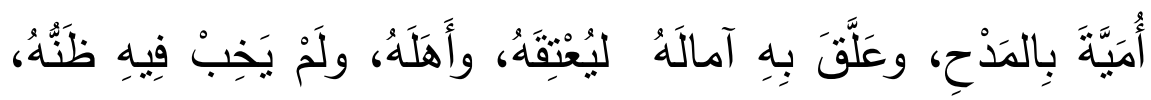

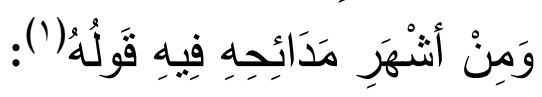

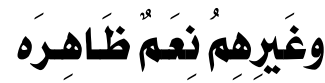

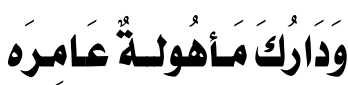

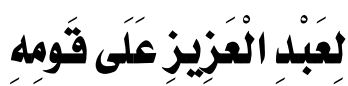

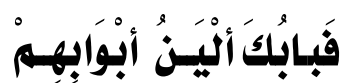

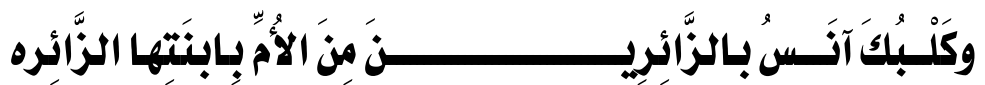

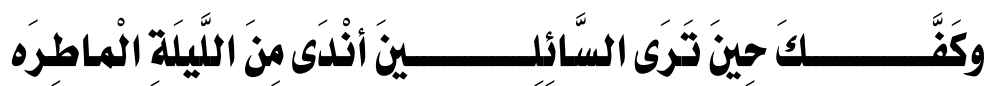

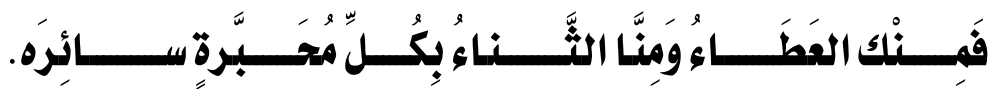

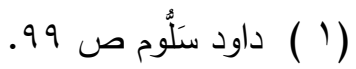

盟 $\Lambda \cdot \Lambda$ 影 


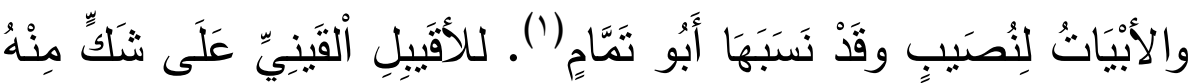

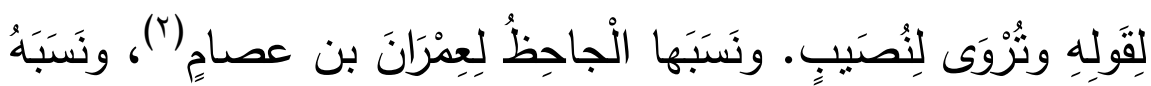

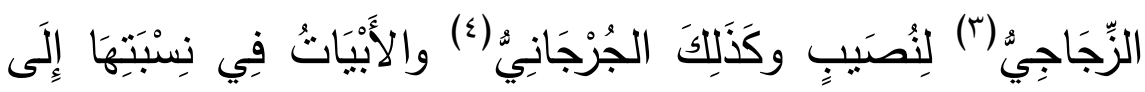

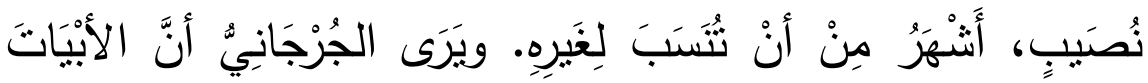

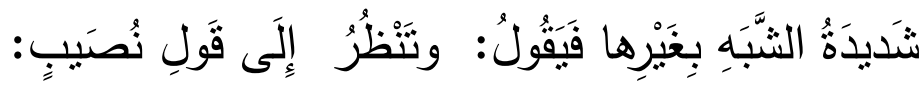

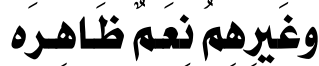

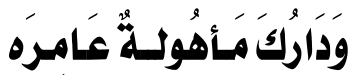

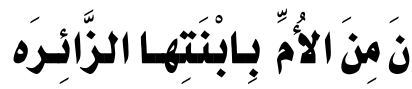

يُكَلِمُهُ مِنْ حِبِهِ وَهْوَ أعْجِهُ
لِعبدِ العَرْيزِِ عَلَى قَومِهِ

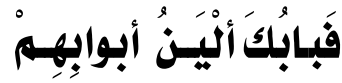

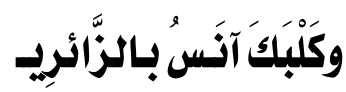

فَتَعْلَمُ أَنَّهُهُ مِنْ قَوَلِ الآخَرِ

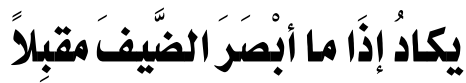

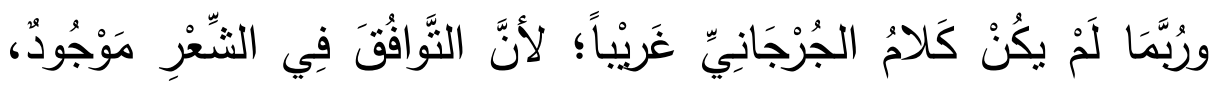

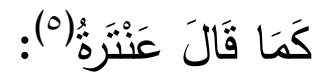
أَمْ هَلْ عَرَفْتَ اللَّارَرَبَعْدَ تَوَهُهُمِ

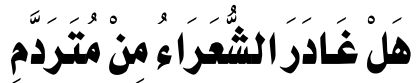

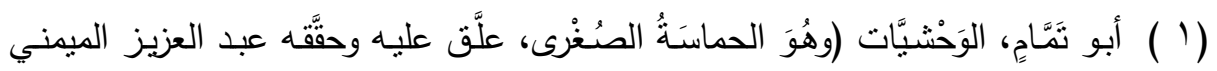

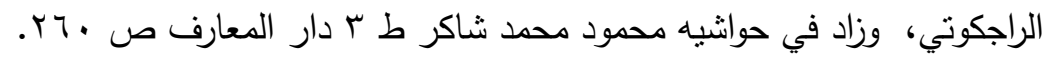

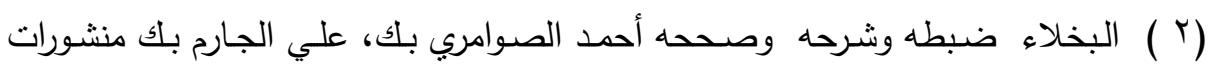

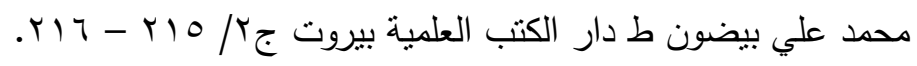

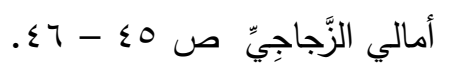
د دلائل الإعجاز - قرأه وعلَّق عليه أبو فهر محمود مُحَّمد شاكر ص 9 ـ.r.

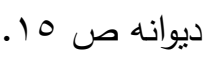




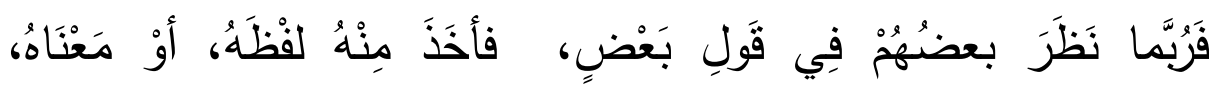

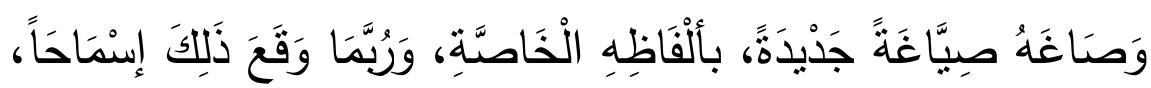

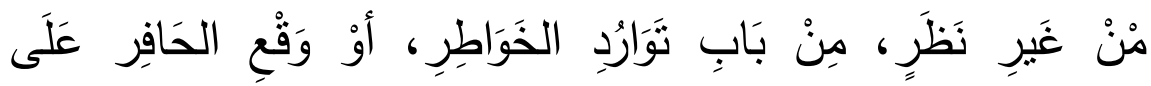

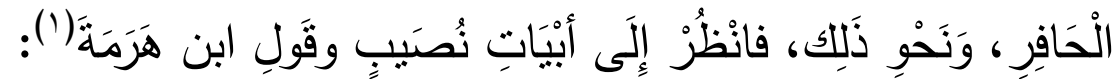

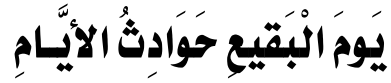

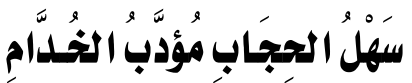

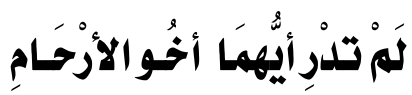

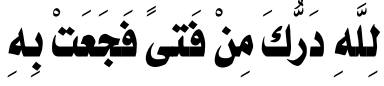

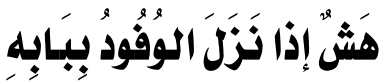

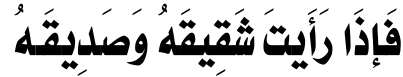

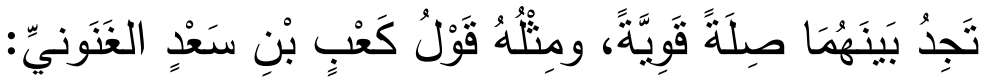

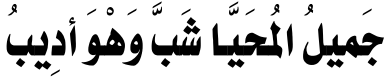

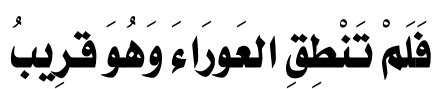

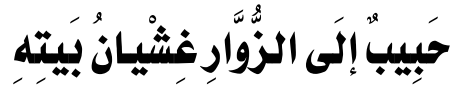

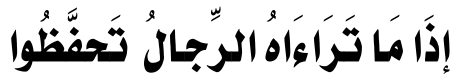

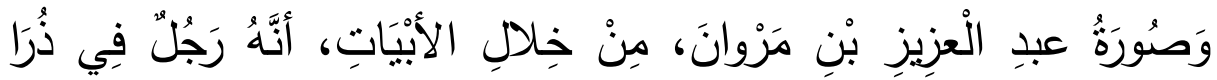

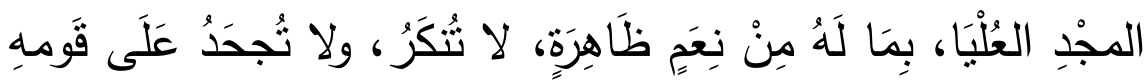

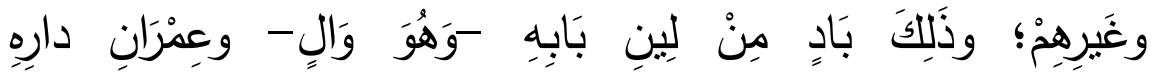

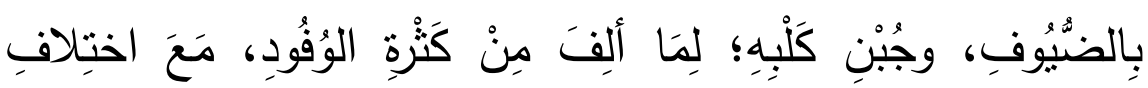

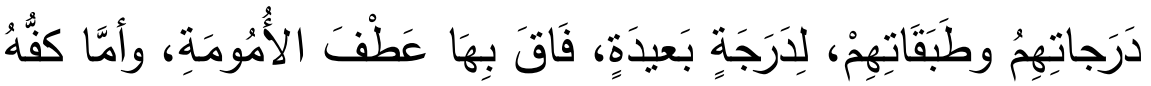

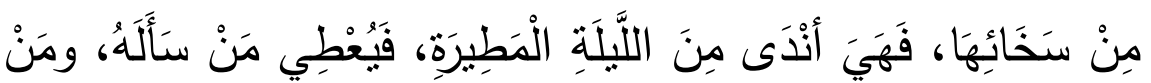

(1 ) البيان والتبيين، تح عبد السَّلام مُحمَّد هارون طץ الناشر مكتبة الخانجي بمصر ومكتبة

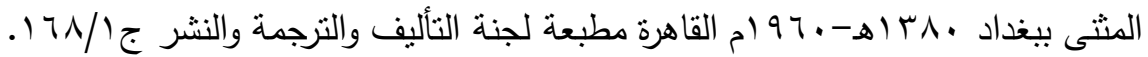




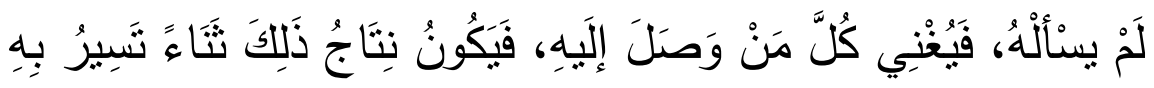

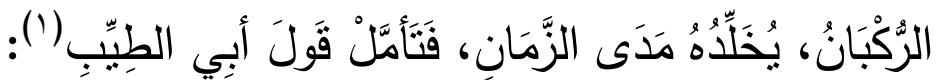

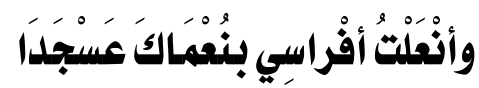

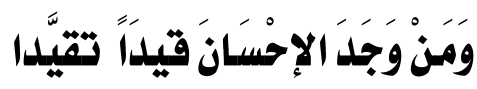

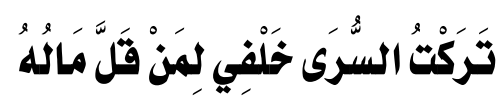

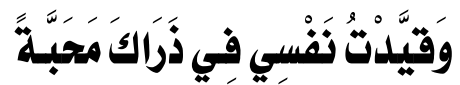

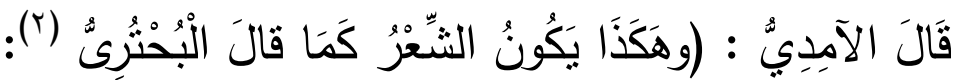

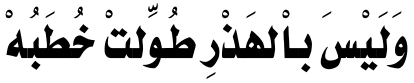

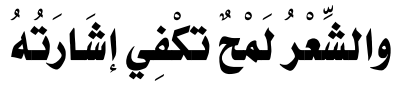

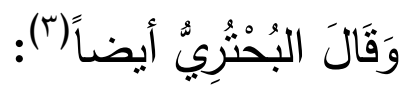

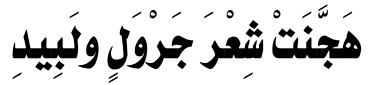

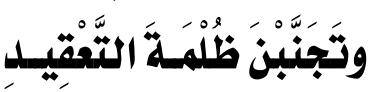

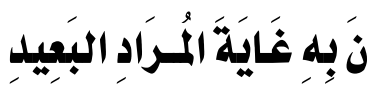

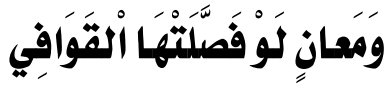

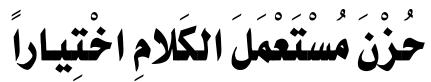

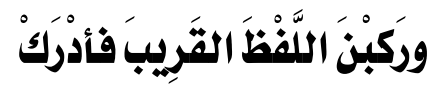

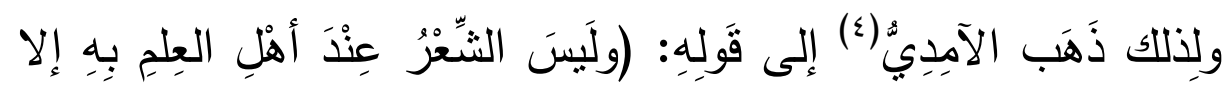

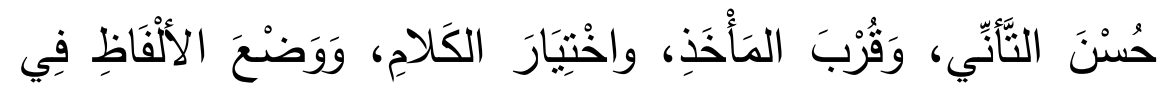

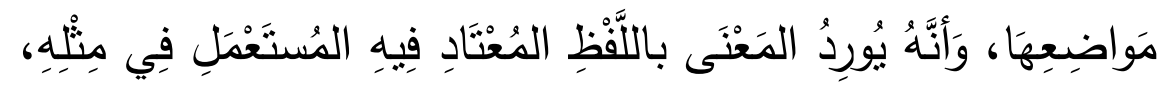

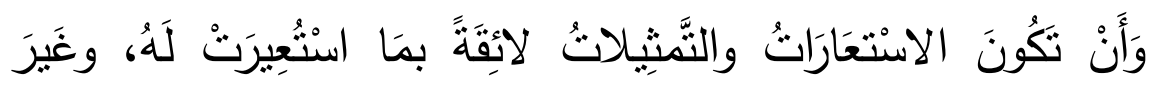

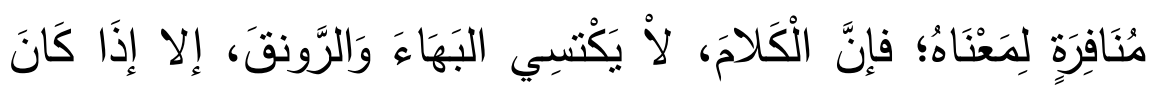

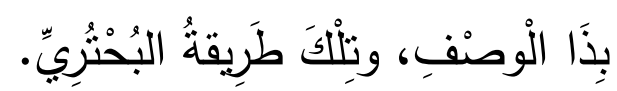

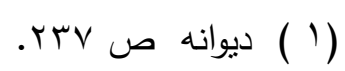

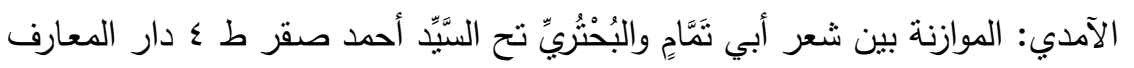

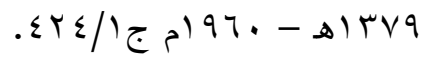

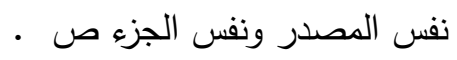

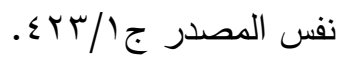




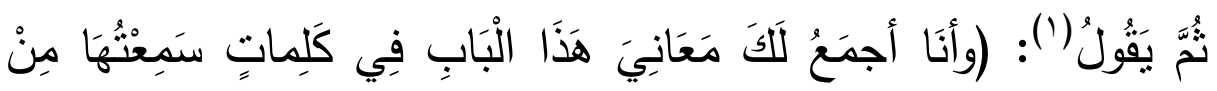

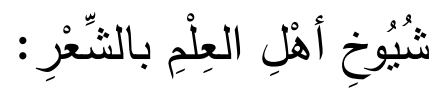

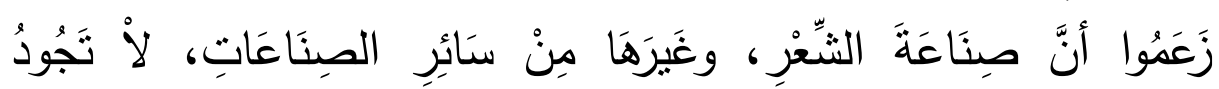

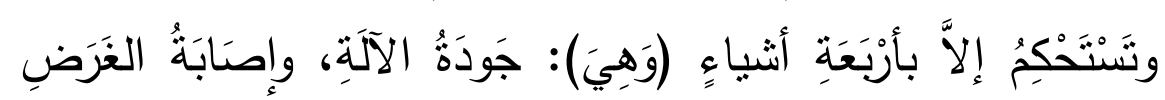

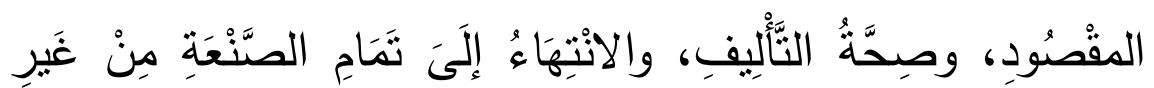

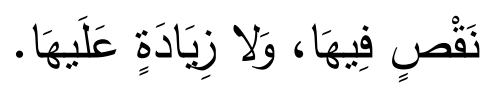

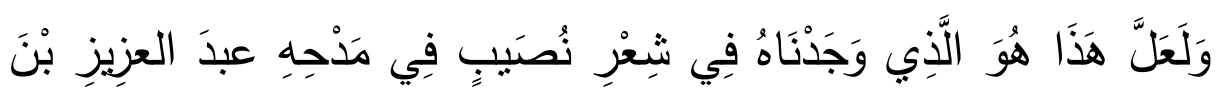

سَقَتْكَكَ الْفَوَادِي مِنْ مْرَاحِ ومَمْزَبِ

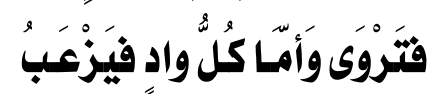

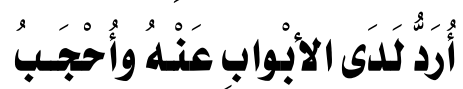

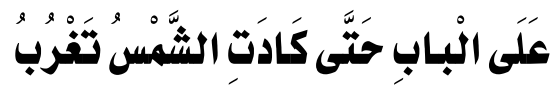

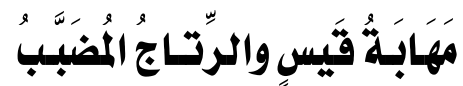

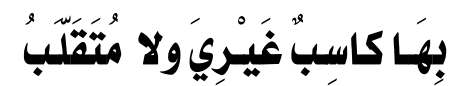

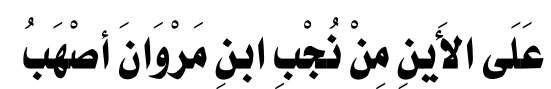

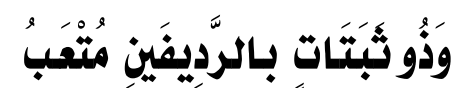

$$
\begin{aligned}
& \text { مَزْوانَ. }
\end{aligned}
$$

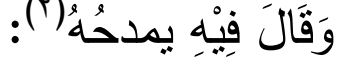

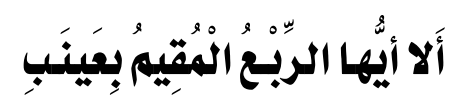

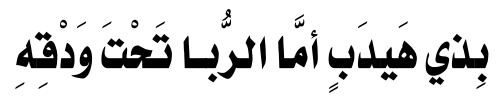
ألالْ هَلْ أَتَى الصَّقَّرَ ابْنَ مَرَوْانَ أَنَّنِي

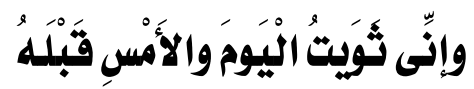

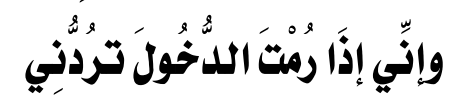

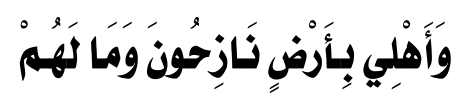

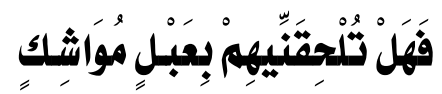
أبو بَكرَاتِ إنْ أُرَدَتَ افْتِحَحَالَهُ 


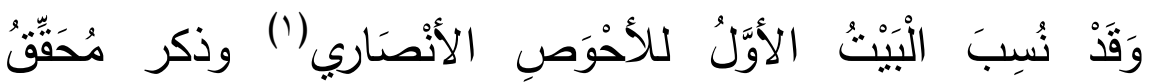

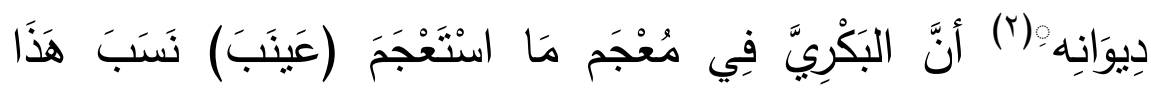

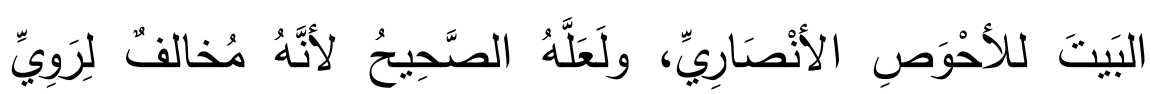

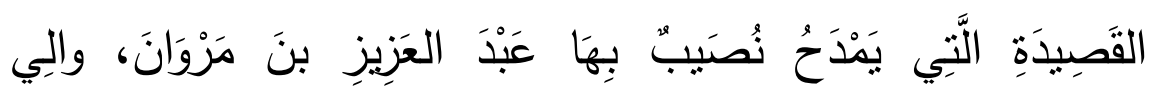

مَصرَ •

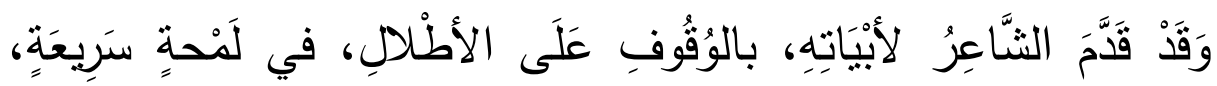

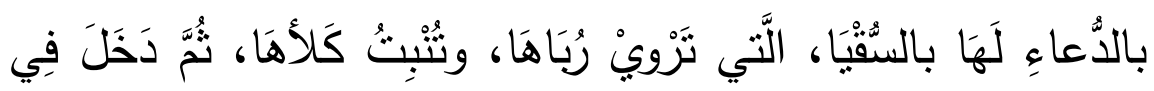

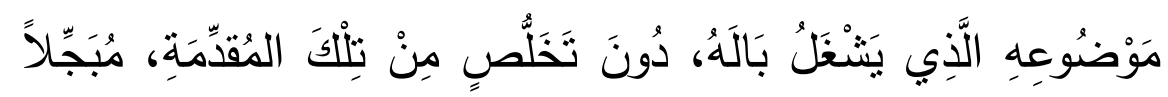

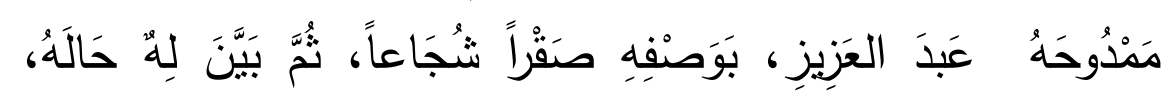

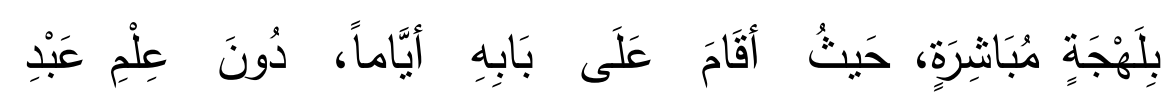

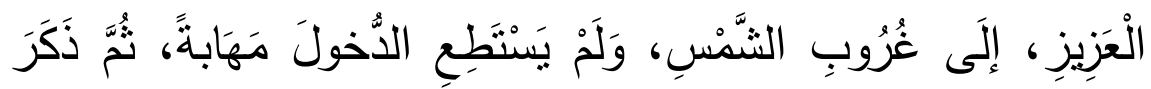

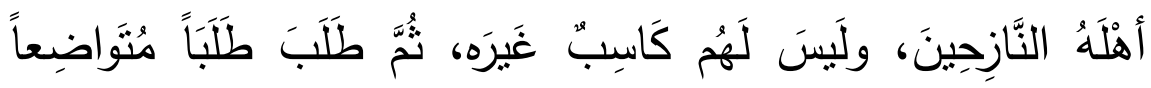

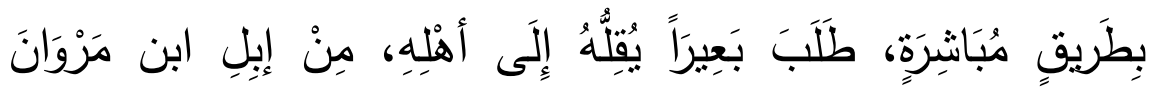

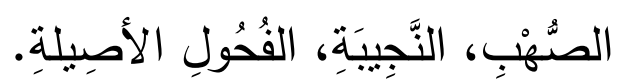

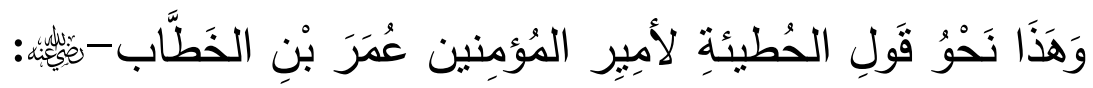

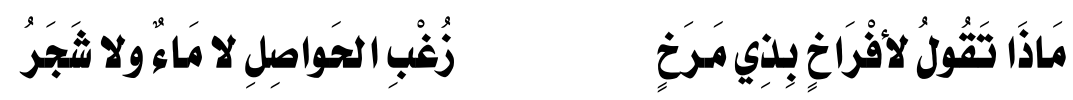

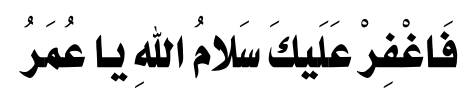

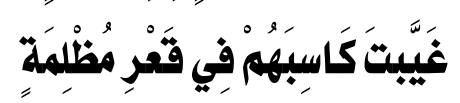

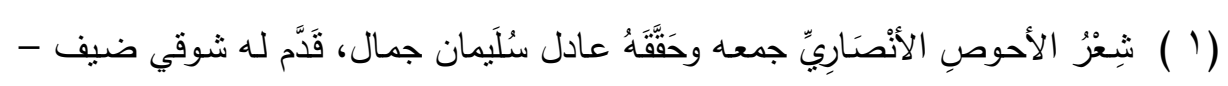

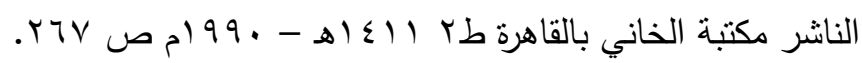
(r) ( ) نفس الصَّفحة (الهامش). 


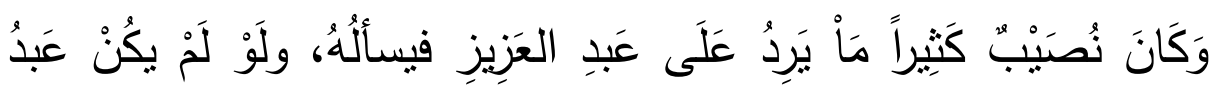

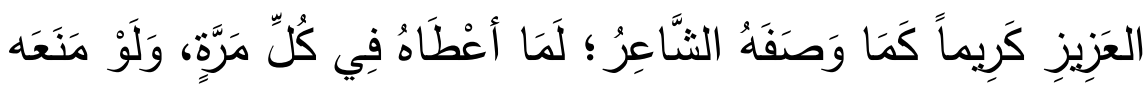

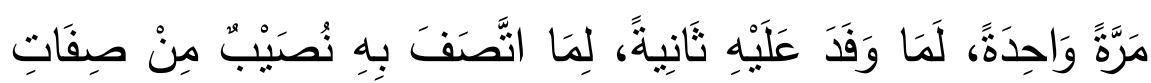

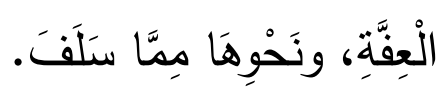

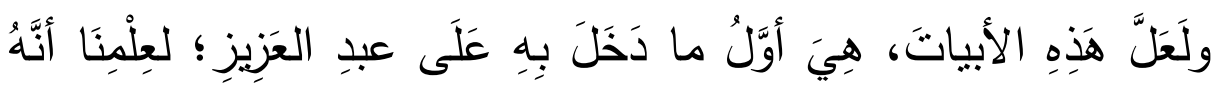

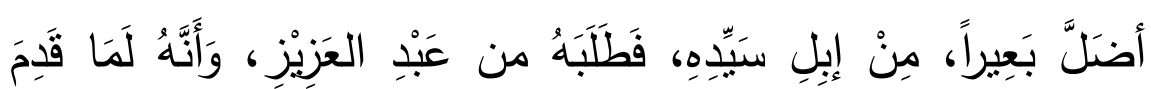

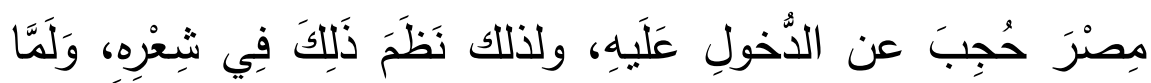

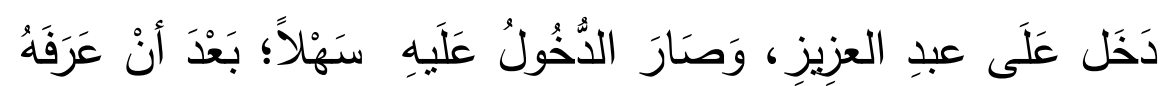

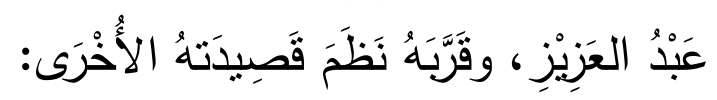

ودَارُكَ مَأْهُوَلَلْهُ عَامِرَهْ

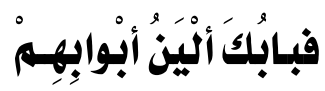

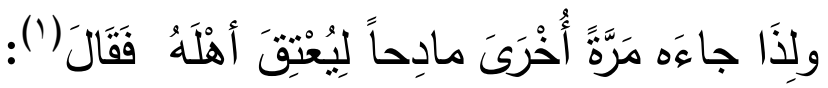

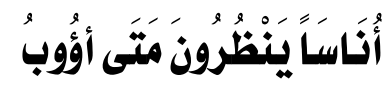

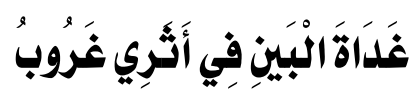

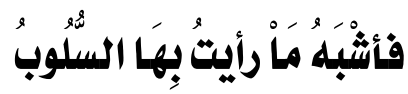

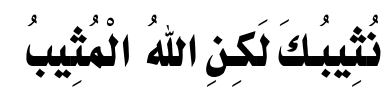

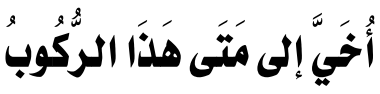

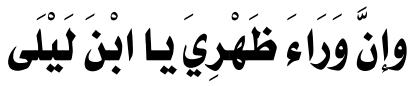

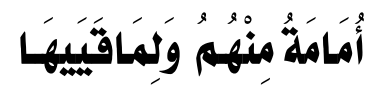

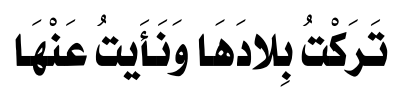

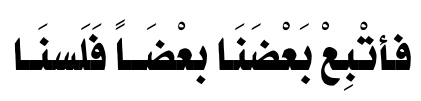

$$
\text { وَقَََالَ أَيْضَاً (r): }
$$

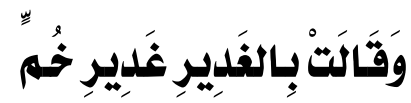

$$
\begin{aligned}
& \text { ( ) ( ) داود سلُؤم، ص بآ. }
\end{aligned}
$$

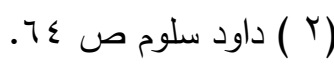




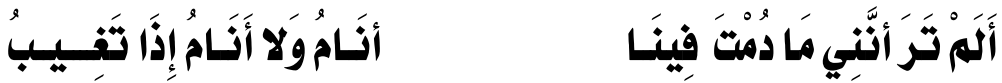

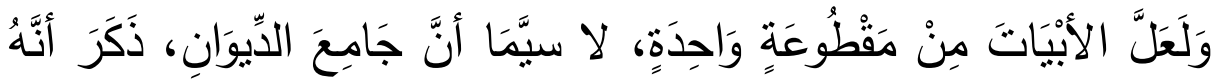

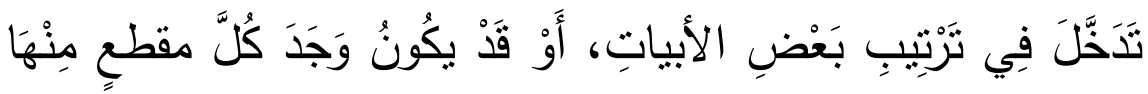

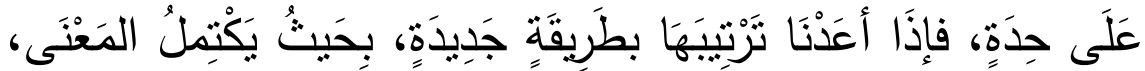

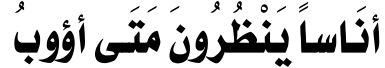

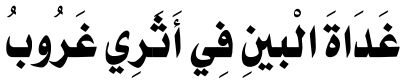
أُخْيَّ إلى مَتَى هَذًَا الرُّكُوبُ

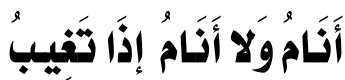

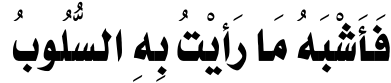

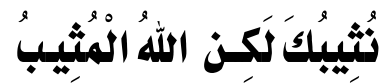
لَكانَ حَسَناً سائِغاً كَمَا يلِي

وَإِنَّ وَرَاءَ ظَهَرِيَِيَا ابْنَ لَيْلَى

أُمَامَهُة منْهُهُ وَلمَاقِيَهَهَا

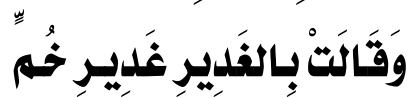

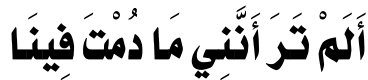

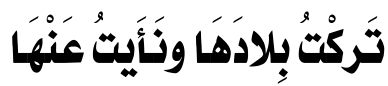

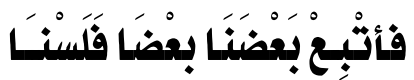

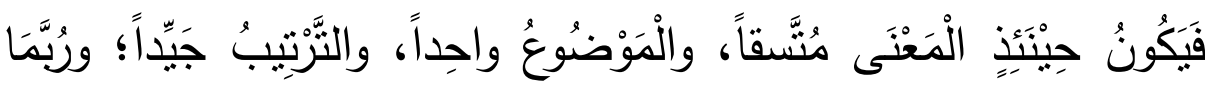

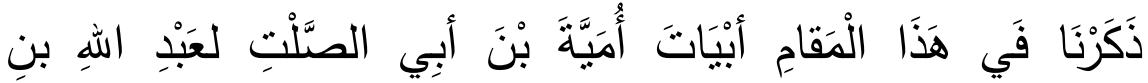

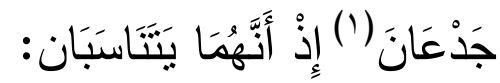

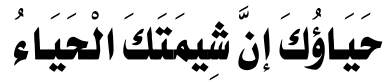

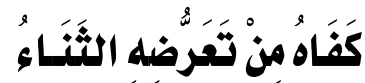

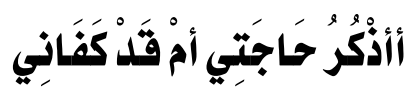

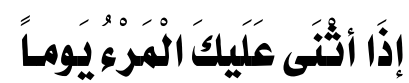

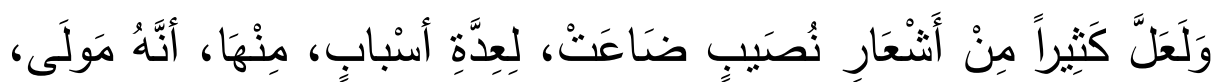

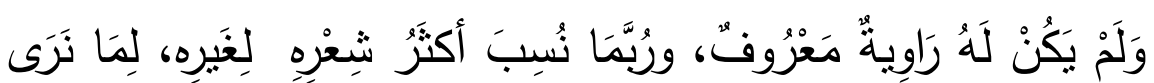


مِنْ نَضَارُبِ الرِّوايَاتِ، فِي نِسْبَةِ أنثعارِه، كَمَا مَرَّ رِنَا فِي النَّصِّ

$$
\text { السَّابِق: (لِعَبِد العزيزِِ عَلَى قَوْمِهِ) }
$$

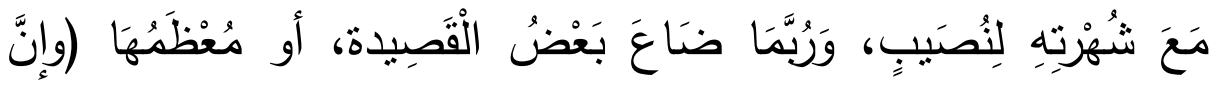

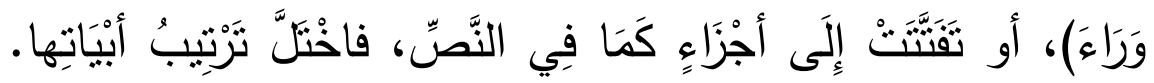

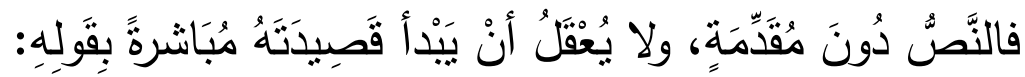

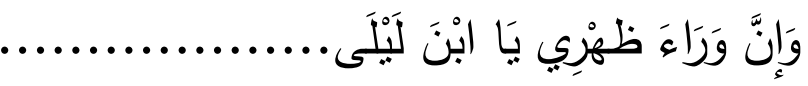

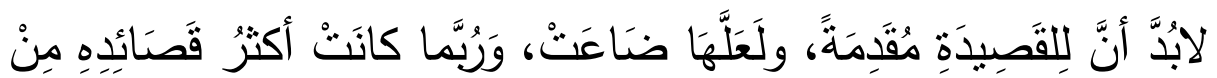

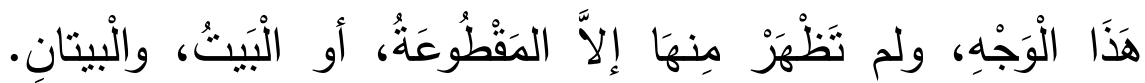

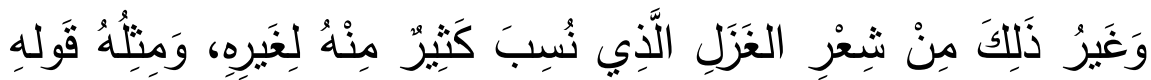

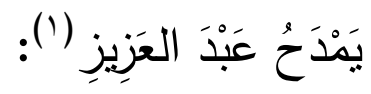

وَيَفْعَلْ فَوقَ أَحْسَنِ مَا يَقُولُ

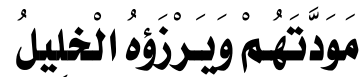

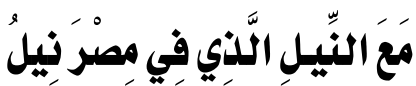

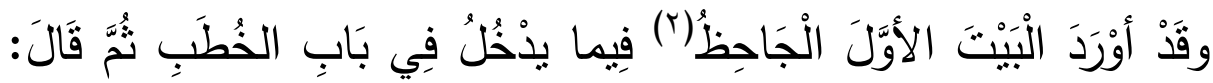

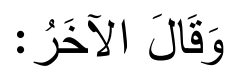

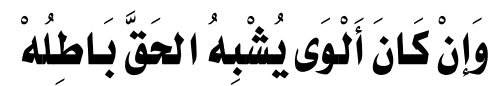

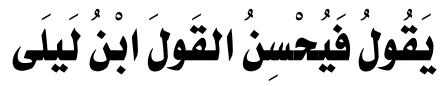
فَتَى لا يَرَزْأُ الْخَهـلانَ إِلا

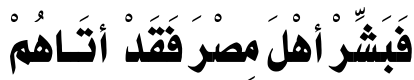




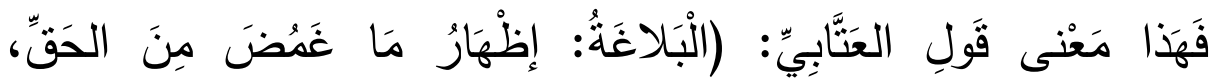

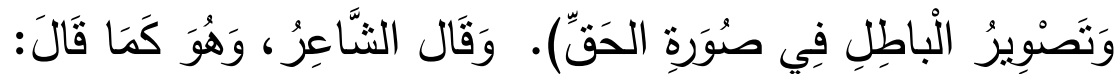

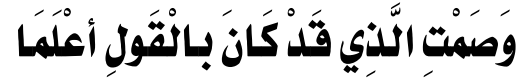

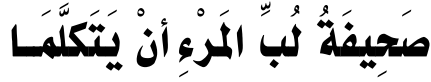

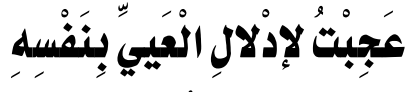

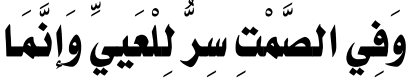

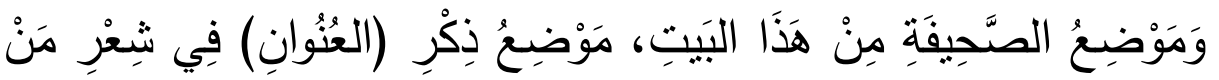

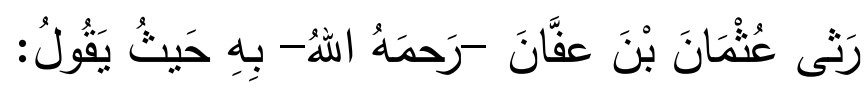

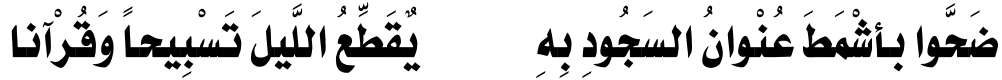

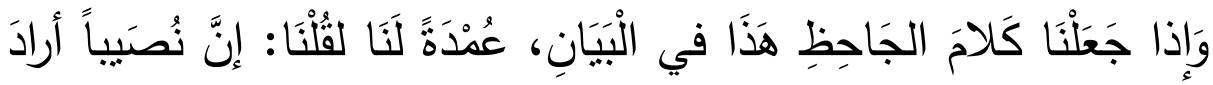

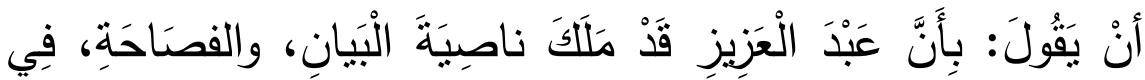

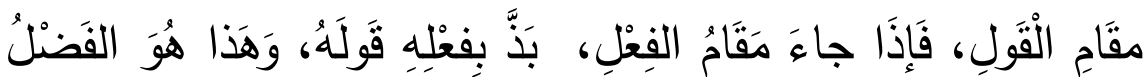

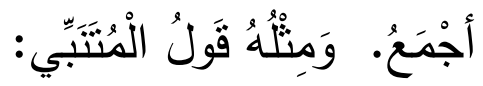

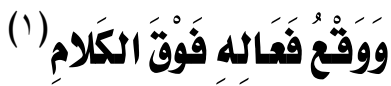

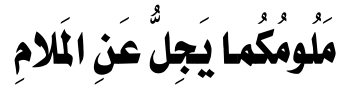

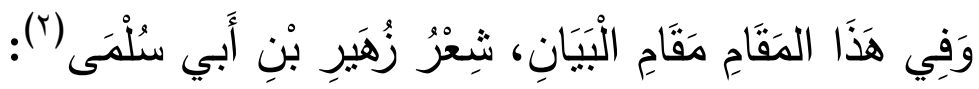

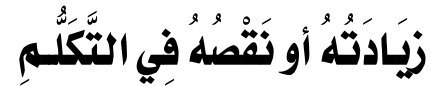

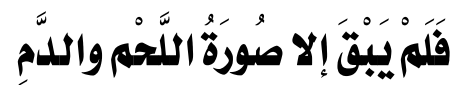

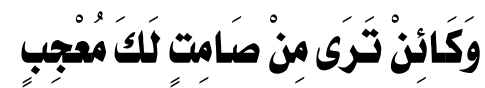

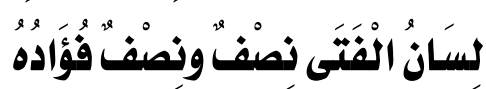




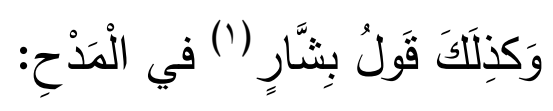

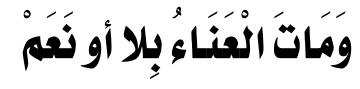

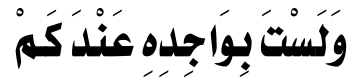

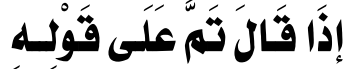

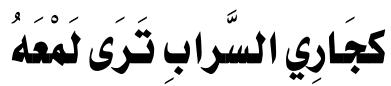

لَوَْكُنْتَ تَفَفْلَ مَمَ تَقَقولْ

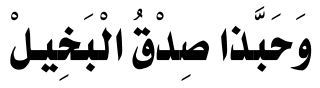

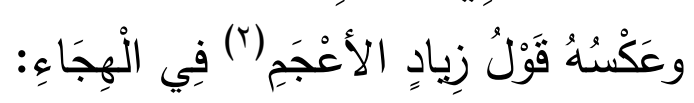

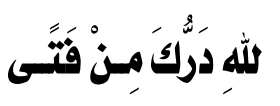

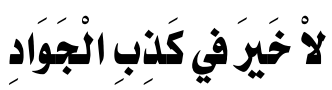

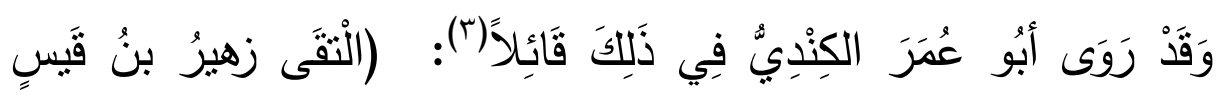

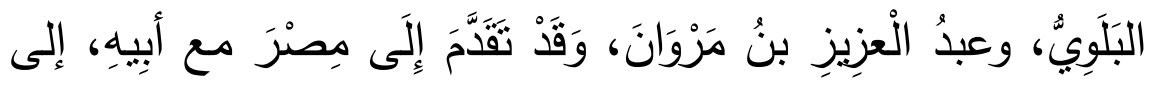

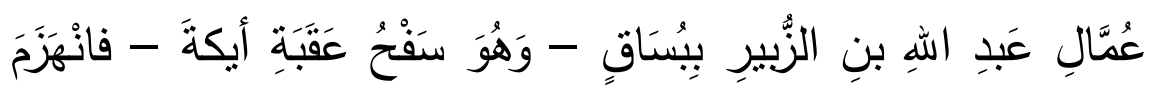

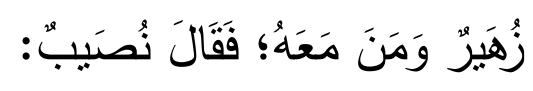

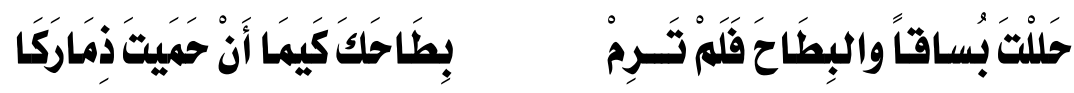

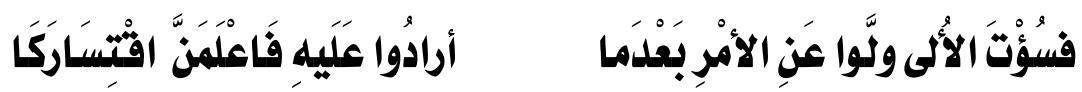

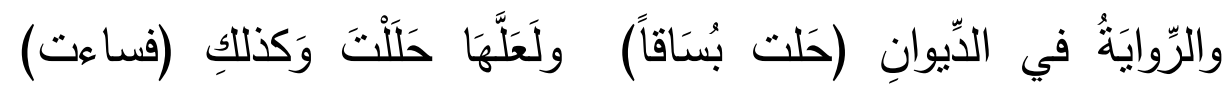

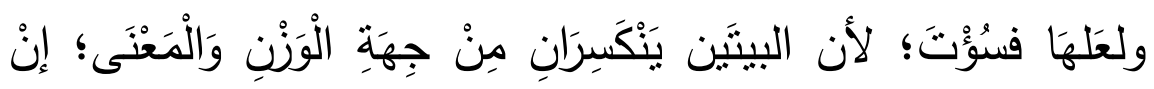

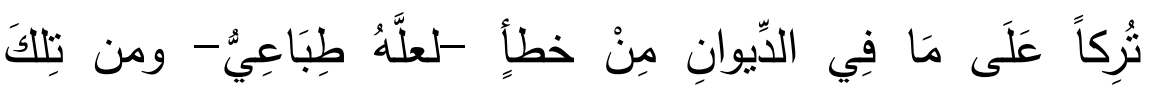

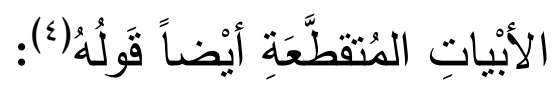

يُفْنِي مَكانَكَ أَوْعُطِيَ كَما تَهَبُ

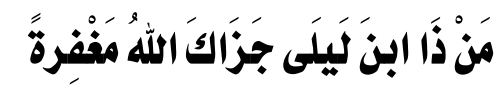

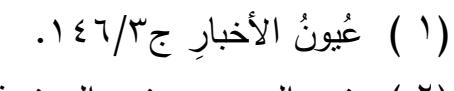

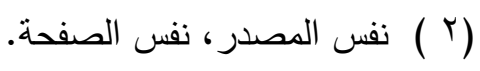

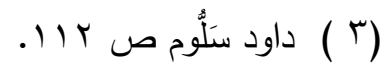

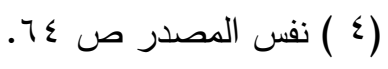




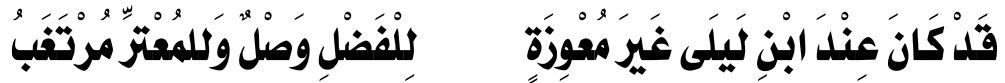

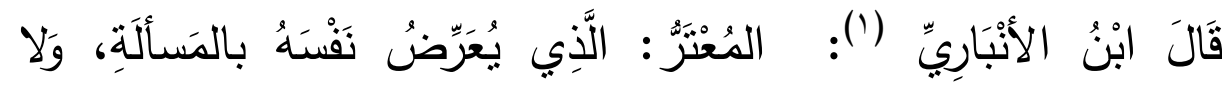

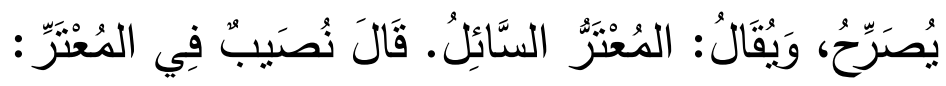

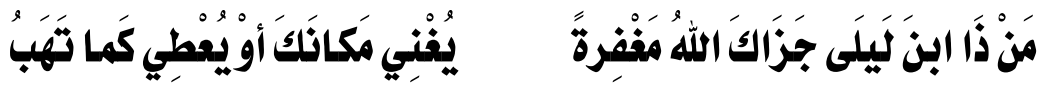

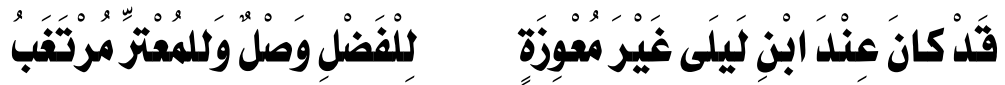

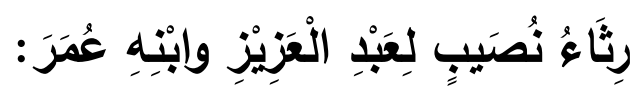

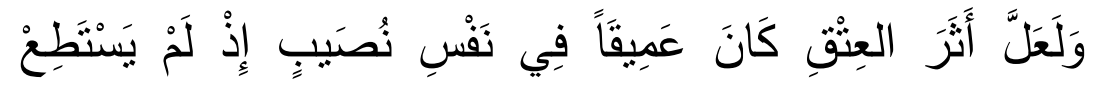

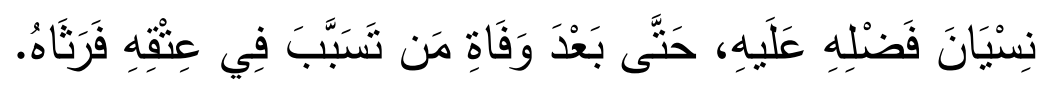

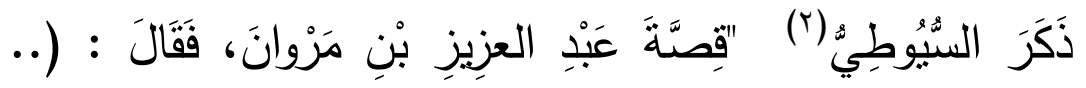

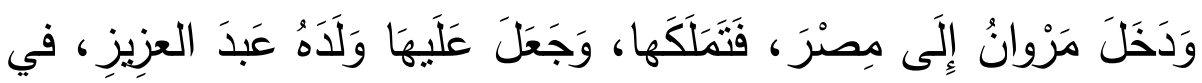

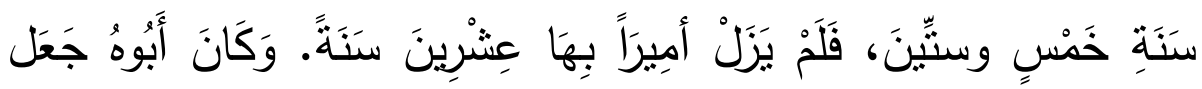

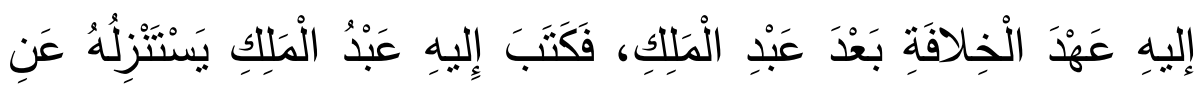

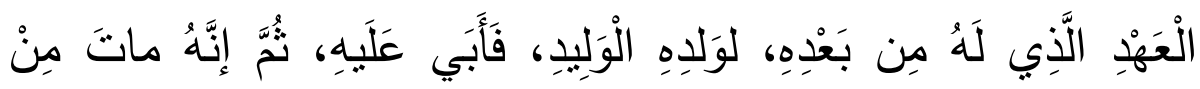
عَامِهِ.

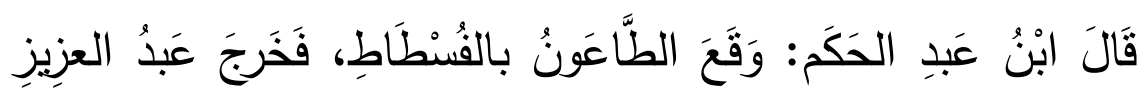

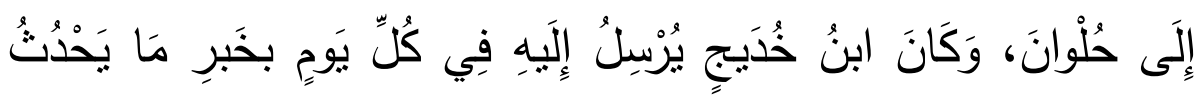

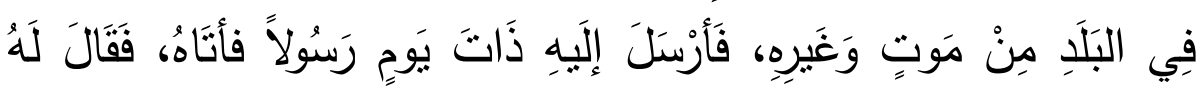

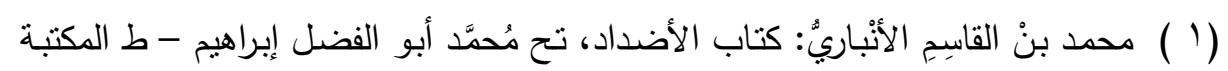

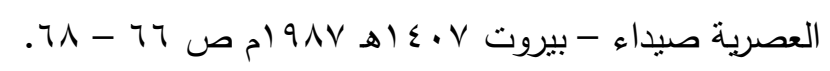

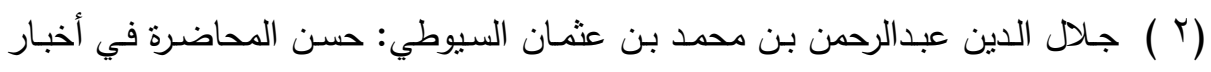

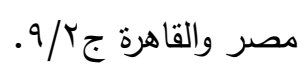




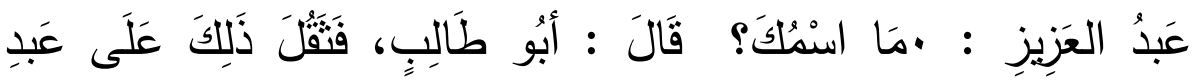

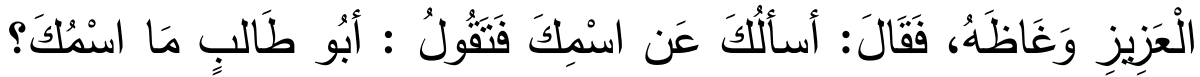

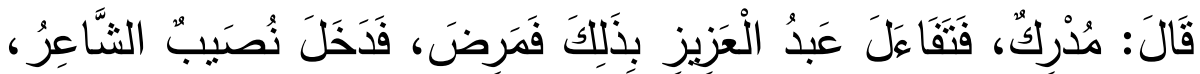

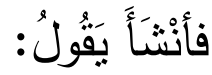

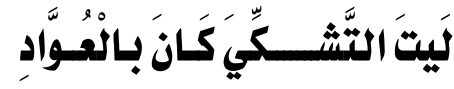

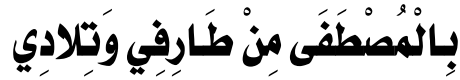

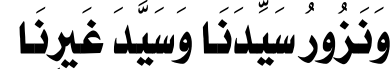

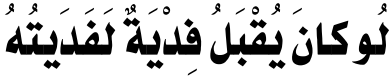

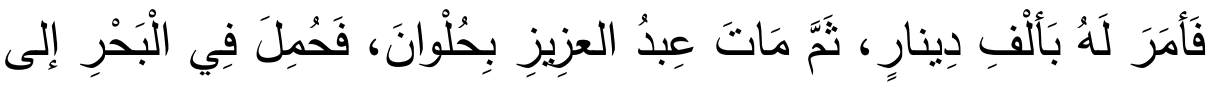

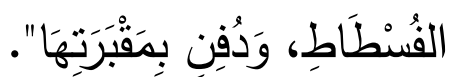

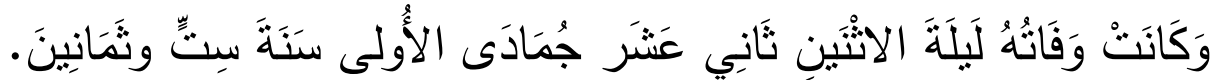

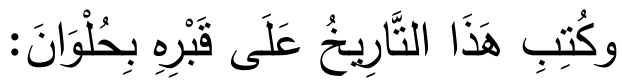

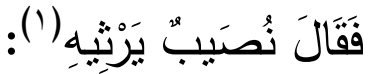

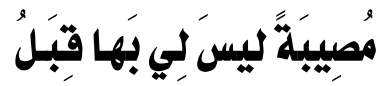

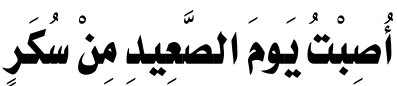

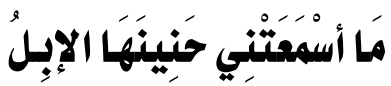

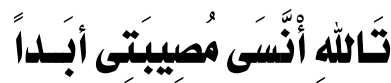

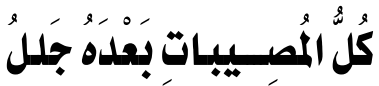

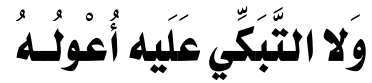

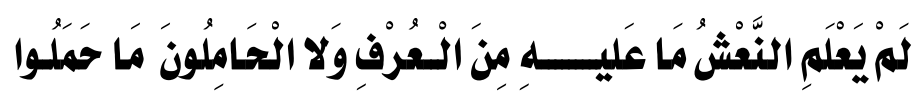

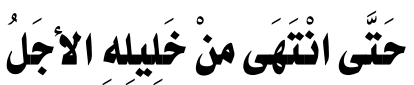

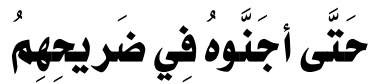

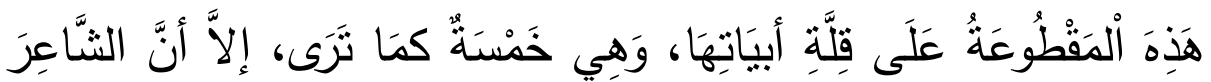

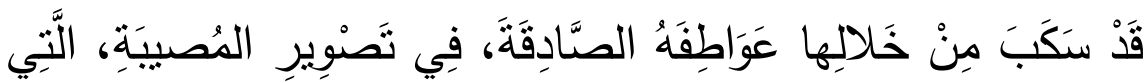

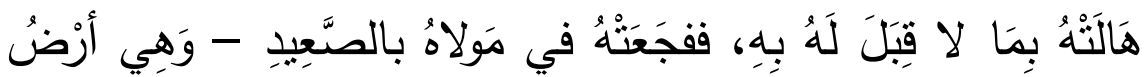




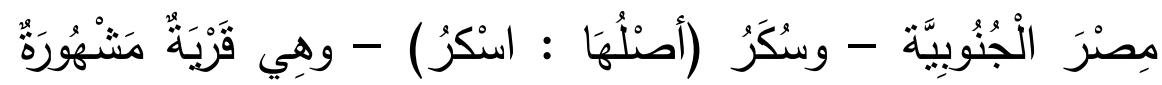

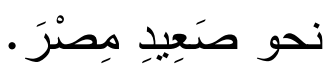

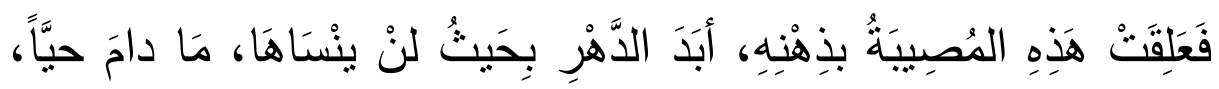

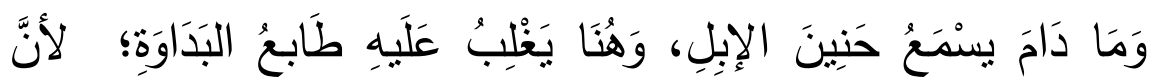

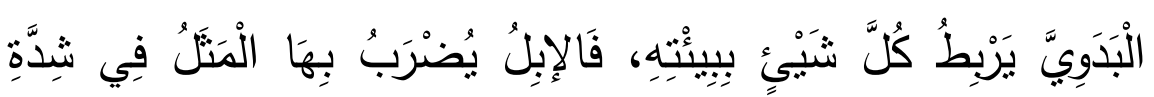

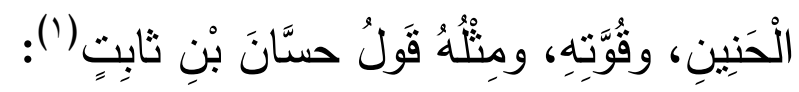

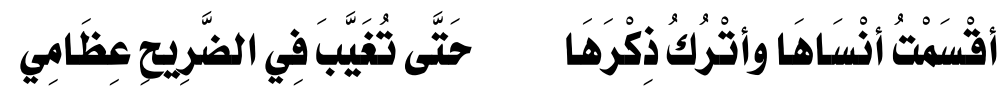

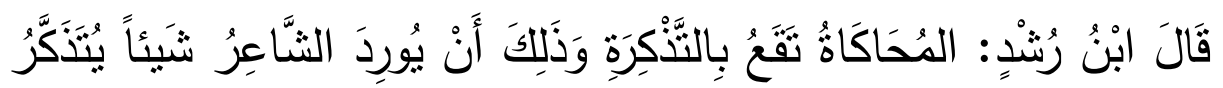

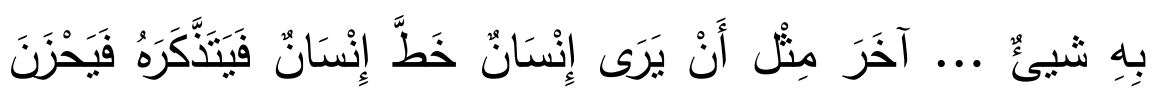

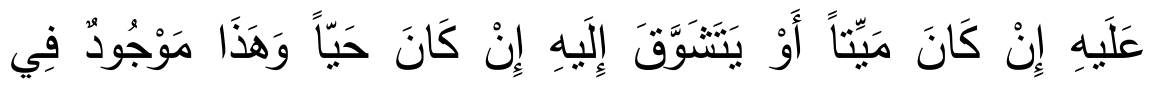

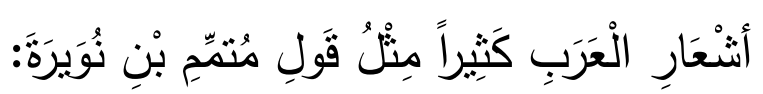

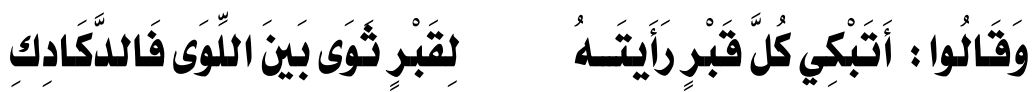

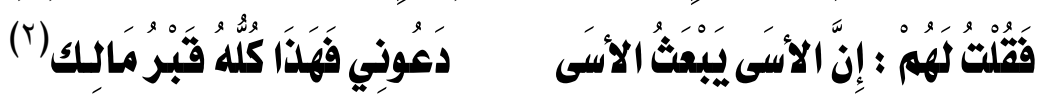

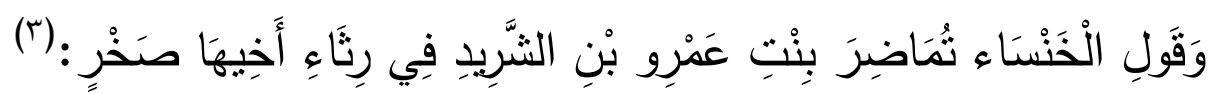

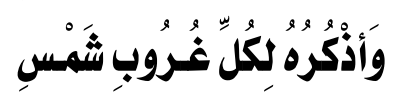

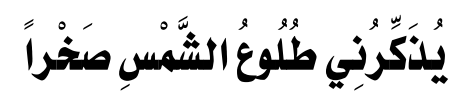

$$
\begin{aligned}
& \text { ديوانه تح سيد حنفي حسنين ط ا دار المعارف ص ^ •. 1. }
\end{aligned}
$$

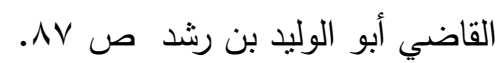

تلخيص كتاب أرسطوطاليس في الثعر ترجمهـ عن اليونانيـة وشرحه وحقق نصوصده عبد

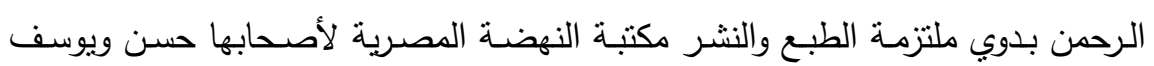

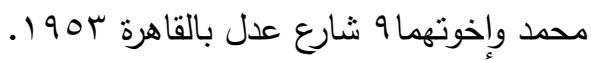

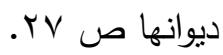


أَبِي حَسَّانَ لَنَّاتَّبِ وأُنْسِي

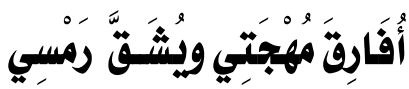

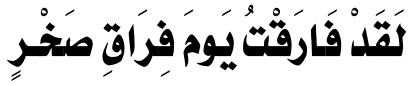

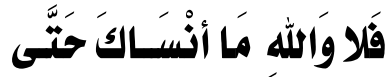

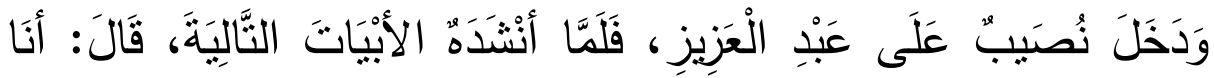

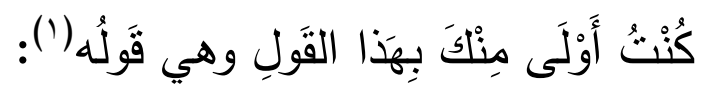

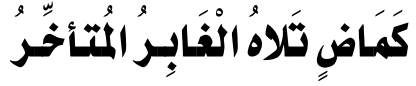

يَمَرُونَ أَسْلافَاً أمَامِي وَأَغْبَبَرُ

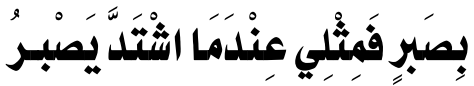

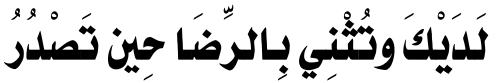

ذُرَاَهَا لَمنْ لاقَتَتْ مِنَ النَّاسِ

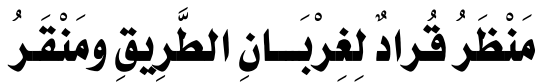

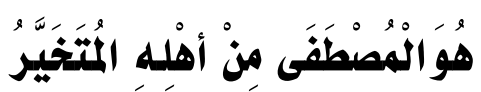

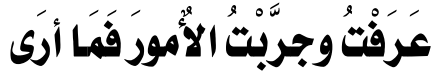

ولكِنَ أََْلَ الفَضْلْ مِنْ أهلْلِ نِعْمَتِي

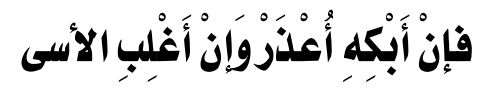

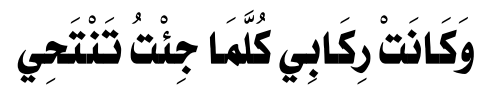

فَقَلْ عَرَيَتِ بَعْدَ ابِنِ لَيَلَى فإِنَّمَا

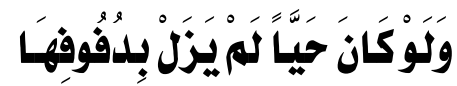

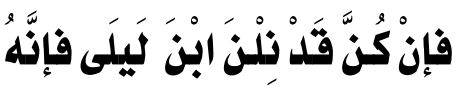

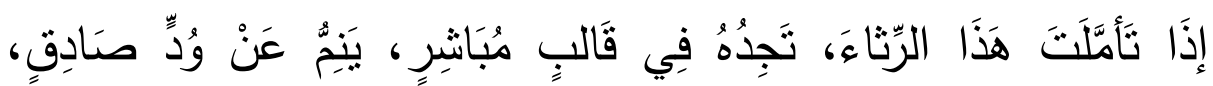

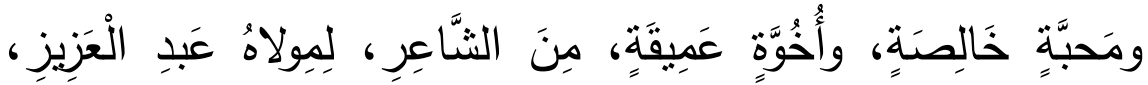

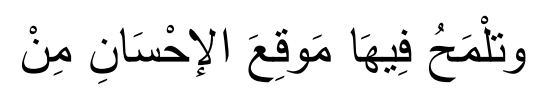

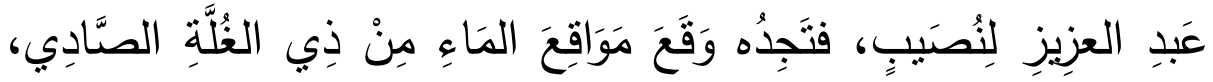

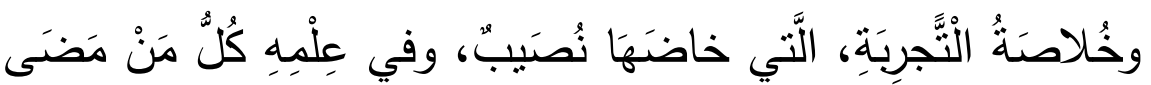

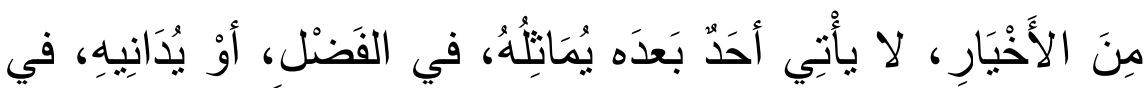

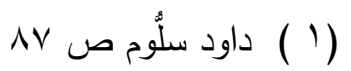

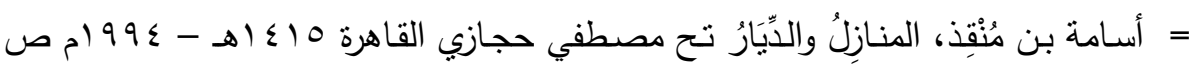




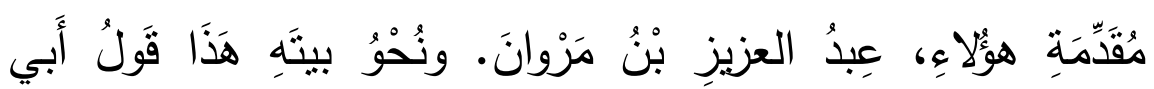

النَّيِّبُ (1)

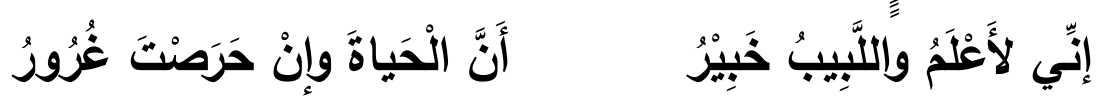

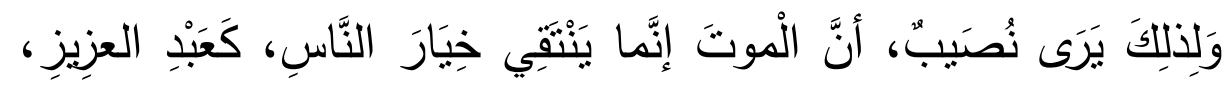

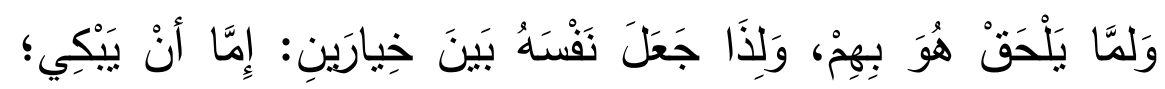

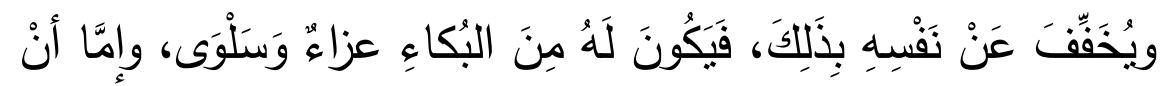

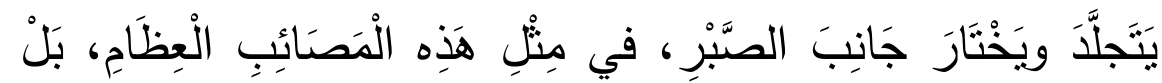

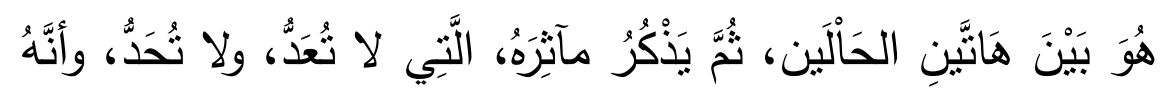

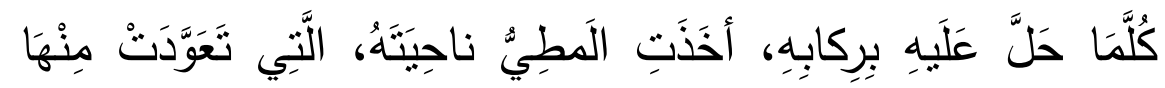

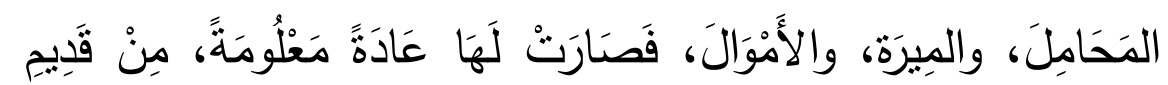

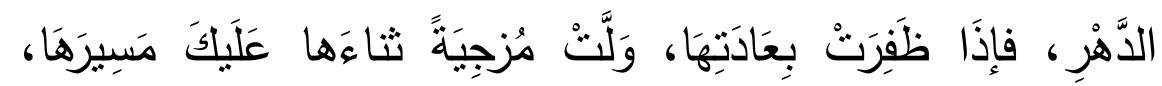

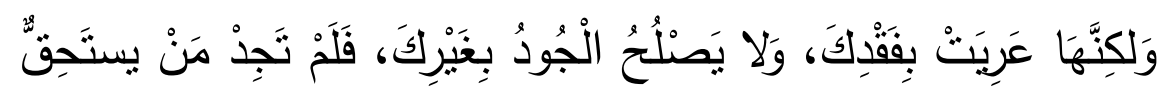

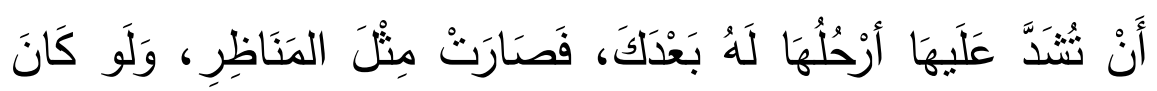

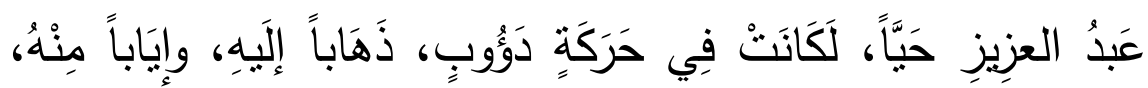

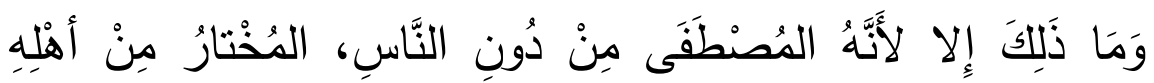
الخِيَارِ

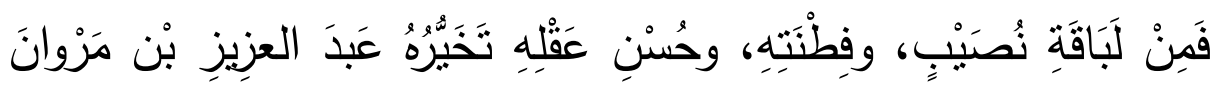

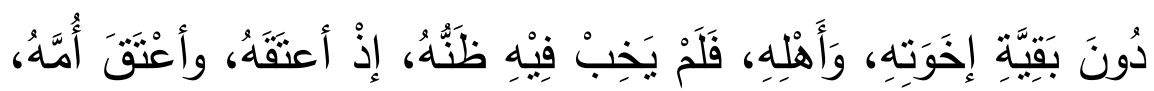

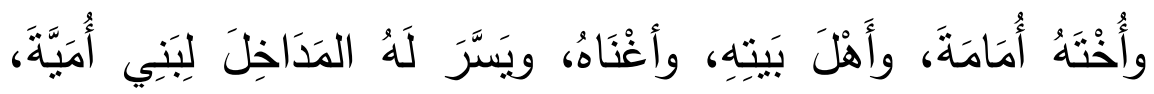




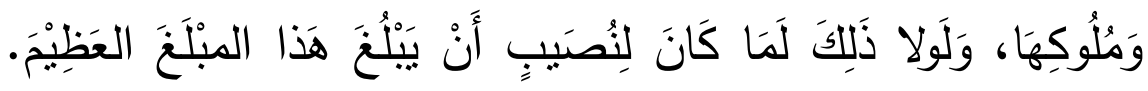

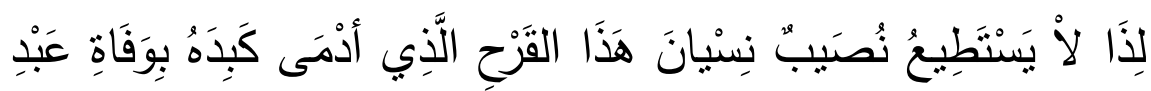

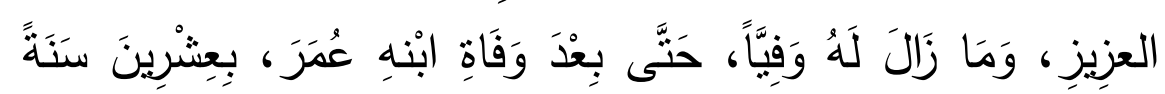

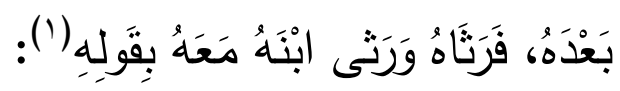

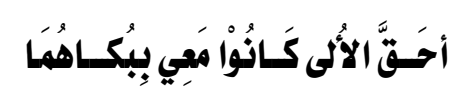

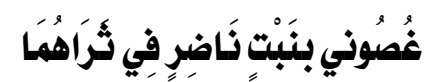

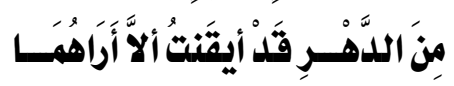

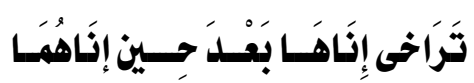

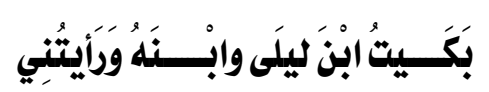

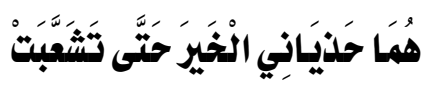

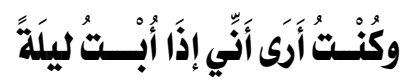

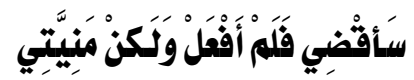

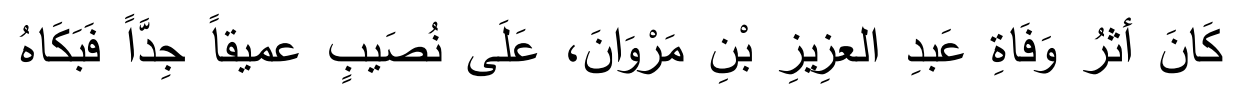

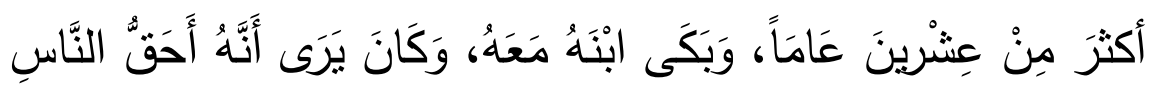

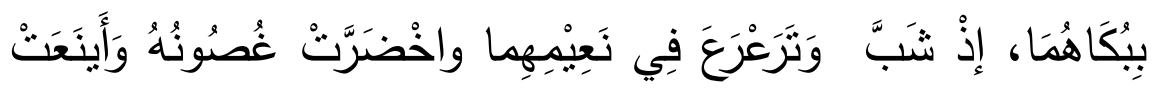

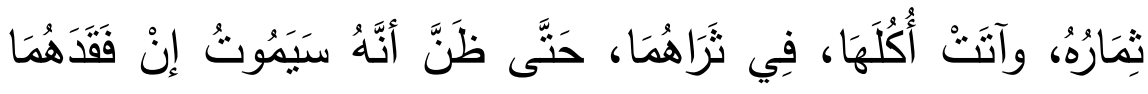

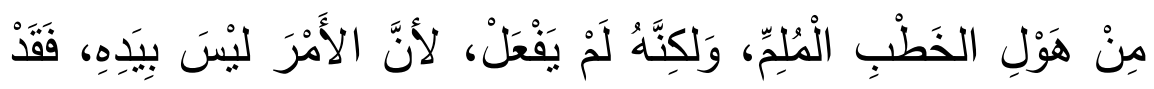

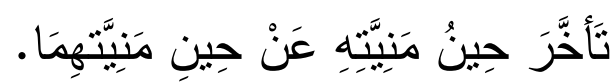




\section{نتائج الدراسة:}

ومن خلال عرضنا لحياة نُصيب ، وتتبُعنا لها في بواطن

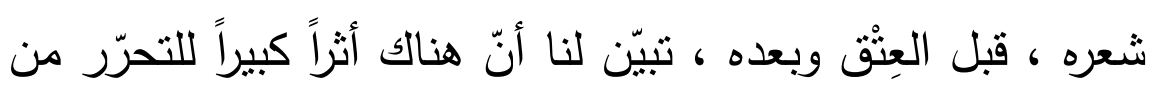

العبودية في حياته ، وفي شعره ، ويتمنّل هذا في النقاط التالية :

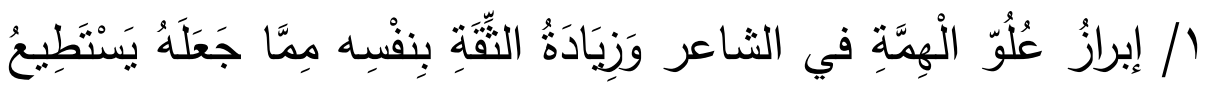

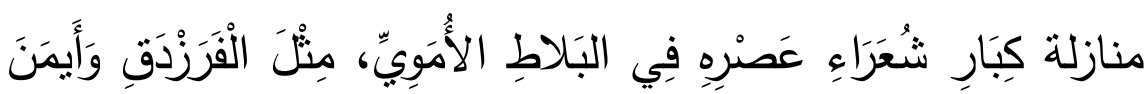

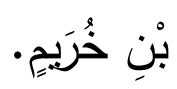

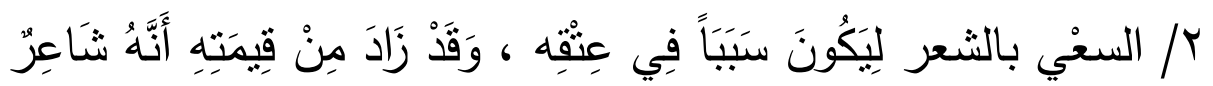
عَالمِ بِالشَّعْرِ وَعَلَلِهِه.

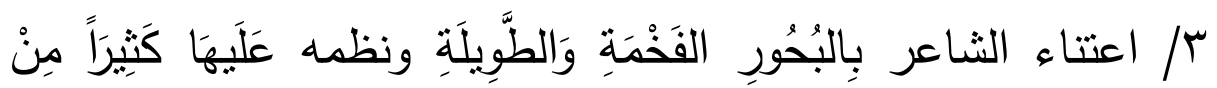

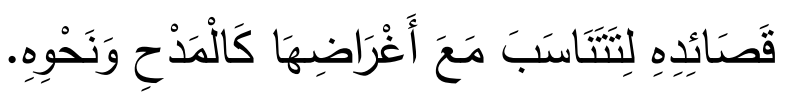

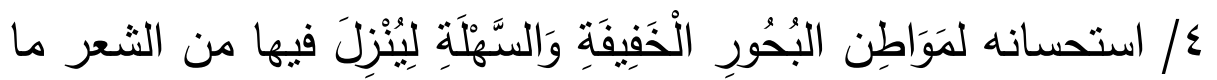
يناسب المقال فيها المقام.

/ مَكثُّف قيمة الحرية لنصيب مما جعله يتكسب بِشِعْرِهِ لعتق جَمِيع أَقَقَرِِِه..

1/ تجلي عنصر الوفاء في شَعر الثشاعر لِمَنْ أَعْنَقَهُ طِيَلَة حَيَاتِهِهِ وَبَعْدَ مَمَاتِهِ. 


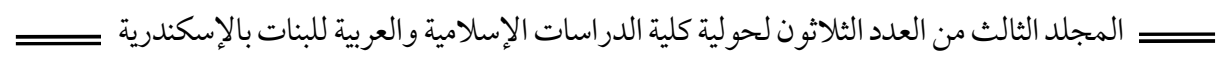

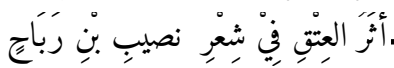

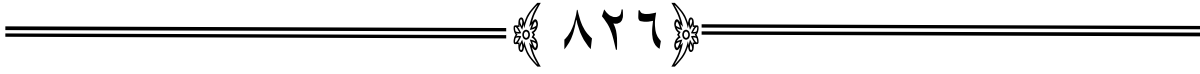




\section{المصادر والمراجع:}

1- الآمدي: الموازنة بين شعر أبي تمام والبحتري تح السيد أحمد

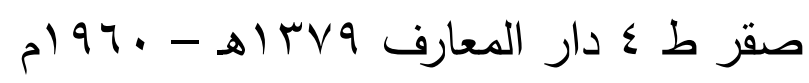

r- الأحوص الأنصاري شعر الأحوص الأنصاري جمعه وحققه

عادل سليمان جمال قدم لله شوقي ضيف الناشر مكتبة الاحسي

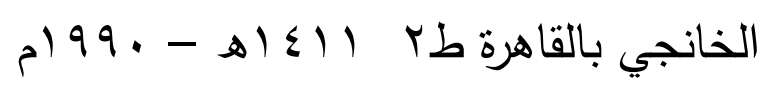

r- الأصفهاني الأغاني أثرف على مراجعته وطبعه العلامة

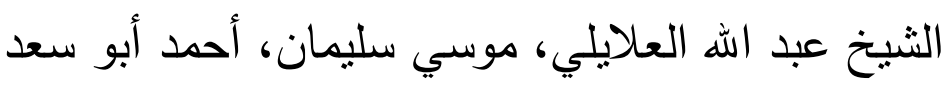

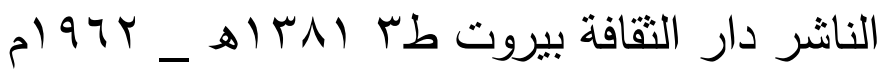

ع - الأعشى الكبير ميمون بن قيس ديوانه دار صادر بيروت

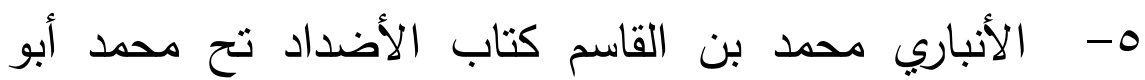

الفضل إبراهيم ط المكتبة العصرية صبدا بيروت

$$
\text { م) } 9 \wedge v-ه \Sigma \cdot v
$$

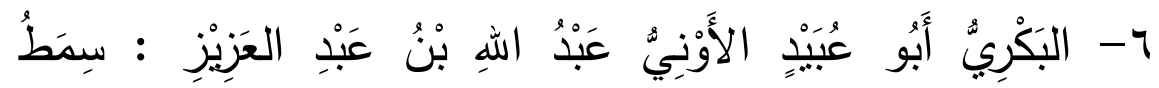

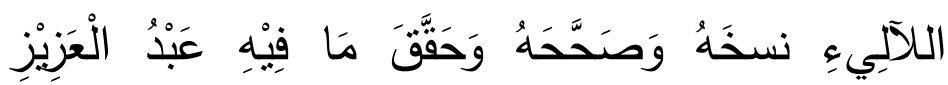

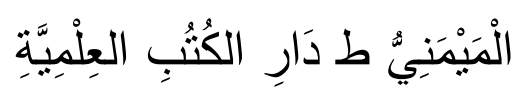

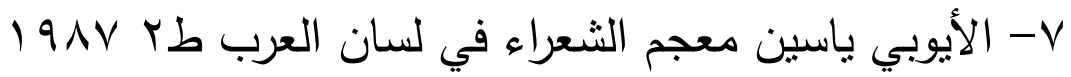




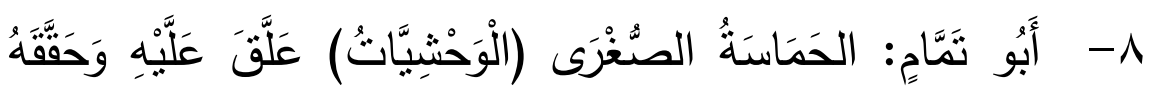

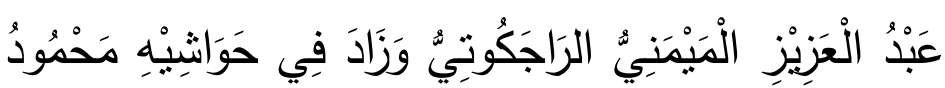

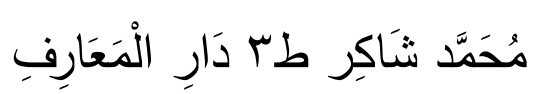

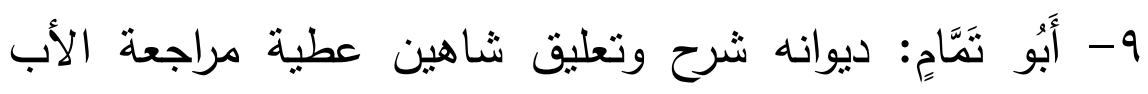

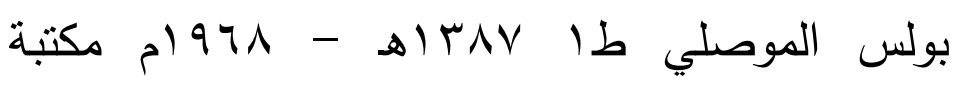
الطلاب وشركة الكتاب اللبناني

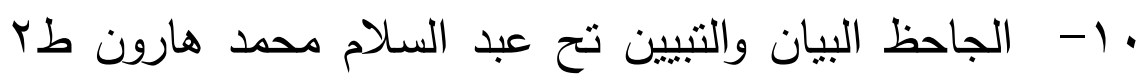
الناشر مكتبة التأليف والترجمة والنشر

1 1- الجاحظ: البخلاء ضبطه وصححه أحمد العوامري بك علي الجارم بك - منشورات محمد علي بيضون دار الكتب

$$
\text { العلمية بيروت لبنان }
$$

r ا - الجاحظ: كتاب البرصان والعرجان والعميان والحولان تح وشرح عبد السلام محمد هارون ط دار الجيل بيروت

$$
\text { م) } 99 .-81 \leq 1 \text {. }
$$

سا- الجرجاني: عبد القاهر الجرجاني دلائل الإعجاز قرأهوعلق عليه أبو فهر محمود محمد شاكر ع ا- الجمحي محمد بن سلام _ طبقات فحول الشعراء ط دار

$$
\text { المدني بجدة }
$$

10 - ابن جني أبو الفتح عثمان بن جني: الخصائص ط المكتبة

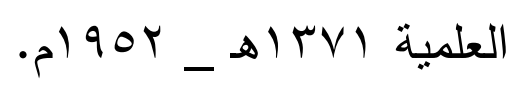


17- المُبهج في تفسير أسماء ديوان الحماسة ط دار الآفاق

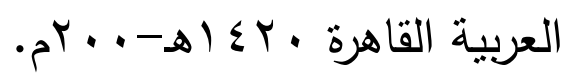

IV

$$
\text { دار المعارف بن بابن }
$$

11- الخضري بك: محمد الخضري بك تاريخ الأمم الإسلامية الدولة الأموية طبعة جديدة ومنقحة تقديم ومراجعة

$$
\text { أحمد حطبط ط دار الفكر اللبناني بيروت }
$$

9 1- ابن خلكان وفيات الأعيان وأنباء أبناء الزمان تح إحسان

$$
\text { عباس ط دار صادر }
$$

•r- الخوارزمي القاسم بن الحسين _ شرح المفصل في صنعة

الأعراب الموسوم بالتخمير شرح عبد الرحمن سليمان

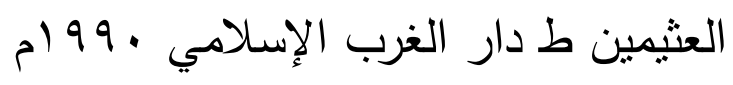

ا Y- داوود سلوم شعر نصيب بن رباح مطبعة الإششاد بغداد

$$
\text { م) } 97 \mathrm{~V}
$$

r r- ابن دريد تعليق من أمالي بن دريد تح السيد مصطفي السنوسي ط ا قسم التراث العربي - المجلس الوطني

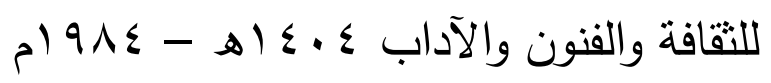

بr- الدماميني بدر الدين أبو عبد الله محمد بن أبي بكر العيون الغامزة على خبايا الرامزة تح الحساني حسن عبد الله 
الناشر مكتبة الخانجى بالقاهرة طץ 10 اهـ -

$$
\text { - ค) } 99 \leqslant
$$

ع r- الدينوري أبو حنيفة أحمد بن داود: الأخبار الطوال قدم

له ووثق نصوصه ووضع حواشيه عصام محمد الحاج

علي منشورات محمد علي بيضون ط دار الكتب

$$
\text { العلمية بيروت }
$$

O V - الذهبي _ سير أعلام النبلاء شرح شعيب الأرنؤوط ط

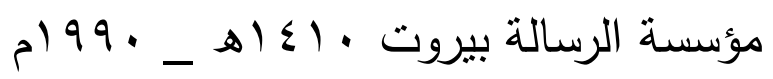

ج - ذو الرمة غيلان بن عقبة ديوانه قدم له وشرحه أحمد حسن

$$
\text { بسج طا 10 19 اهـ ـ } 1990 \text { دار الكتب العلمية }
$$

- ابن رشد تلخيص كتاب أرسطوطاليس في الثعر - تأليف

$$
\text { القاضي أبي الوليد }
$$

^r- الزجاج أبو القاسم عبد الرحمن بن القاسم الأمالي في المشكلات القرآنية والحكم والأحاديث النبوبة ط دار

$$
\text { الكتاب العربي بيروت لبنان }
$$

q - - الزركلي _ الأعلام قاموس ثراجم لأثهر الرجال والنساء من العرب والمستعربين والمستشرقين ط ع ا دار العلم

للماليين بيروت لبنان 1999

• - زهير بن أبى سلمى ديوانه ط دار صادر . 
اب- السيوطي: تاربخ الخلفاء ط دار المنار 9 شارع الباب الأخضر مبدان الحسين

rس- حسن المحاضرة في أخبار مصر والقاهرة وضع حواثيه خليل المنصور منشورات محمد علي بيضون ط دار

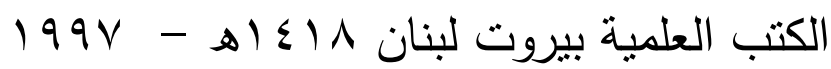

سب- ابن عبد ربه العقد الفربد منشورات دار ومكتبة الهلال

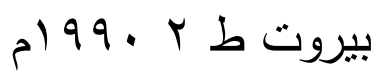

ع س- ابن العبريِّ: تاريخ مختصر الدول ط المطبعة الكاثوليكية

$$
\text { بيروت لبنان } 901
$$

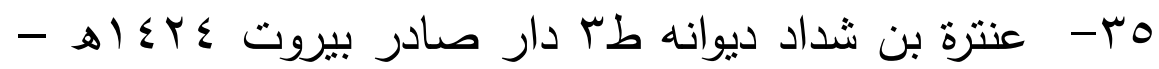

$$
\text { r.? }
$$

جس- الفرزدق همام بن غالب ديوانه تح كرم البستاني ط دار

$$
\text { صادر للطباعة والنشر بيروت. }
$$

V V- ابن قتيبة: الشعر والشعراء تح وشرح أحمد محمد شاكر ط

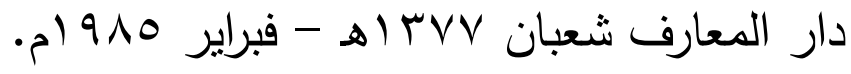

$$
\begin{aligned}
& \text { مب- عيون الأخبار نسخة مصورة عن طبعة دار الكتب }
\end{aligned}
$$

وس- الكتبي محمد بن شاكر الكتبي - فوات الوفيات والذيل

عليها تح إحسان عباس ط دار الثقافة بيروت

• ع- المتتبي أبو الطيب أحمد بن الحسين ديوانه طس دار صادر

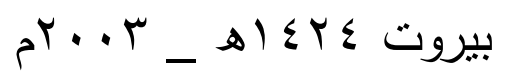


اء- المسعودي: أبو الحسن علي بن الحسين بن علي مروج

الذهب ومعادن الجوهر ط دار الأندلس بيروت بن بن بن

r ؟ - ابن منظور _ لسان العرب نسقه وعلق عليه ووضع فهارسه

علي شيري ط دار إحياء التراث العربي بيروت لينان

$$
\text { م) } 911 \text { _ه } 1 \varepsilon \cdot \Lambda
$$

r؟ - ابن منقذ أسامه بن منقذ المنازل والديار تح مصطفى حجازي

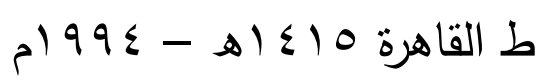

؟ ـ- اليعقوبي أحمد بن إسحاق بن جعفر بن وهب بن واضح:

تاريخ اليعقوبي علق عليه ووضع حواثيه خليل

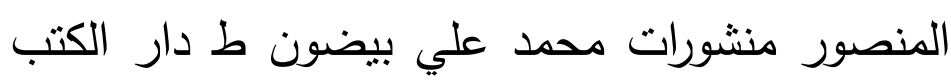

$$
\text { العلمية بيروت }
$$

